\title{
China's Market Economy Dilemma and its Interplay with EU Anti-Dumping Law
}

DOI:

10.1080/10192557.2019.1671664

\section{Document Version}

Accepted author manuscript

Link to publication record in Manchester Research Explorer

\section{Citation for published version (APA):}

Ngangjoh Hodu, Y. (2019). China's Market Economy Dilemma and its Interplay with EU Anti-Dumping Law. Asia Pacific Law Review, 27(1), 102. [1]. https://doi.org/10.1080/10192557.2019.1671664

\section{Published in:}

Asia Pacific Law Review

\section{Citing this paper}

Please note that where the full-text provided on Manchester Research Explorer is the Author Accepted Manuscript or Proof version this may differ from the final Published version. If citing, it is advised that you check and use the publisher's definitive version.

\section{General rights}

Copyright and moral rights for the publications made accessible in the Research Explorer are retained by the authors and/or other copyright owners and it is a condition of accessing publications that users recognise and abide by the legal requirements associated with these rights.

\section{Takedown policy}

If you believe that this document breaches copyright please refer to the University of Manchester's Takedown Procedures [http://man.ac.uk/04Y6Bo] or contact uml.scholarlycommunications@manchester.ac.uk providing relevant details, so we can investigate your claim.

\section{OPEN ACCESS}




\section{Asia Pacific Law Review \\ China's Market Economy Dilemma and its Interplay with EU Anti-Dumping Law --Manuscript Draft--}

\begin{tabular}{|l|l|}
\hline Full Title: & China's Market Economy Dilemma and its Interplay with EU Anti-Dumping Law \\
\hline Manuscript Number: & \\
\hline Article Type: & Original Article \\
\hline Keywords: & $\begin{array}{l}\text { China Market Economy status, WTO Law, EU Anti-dumping legislation, Market } \\
\text { Economy, Compliance, International Law }\end{array}$ \\
\hline Abstract: & $\begin{array}{l}\text { In recent years, the issue of market economy in relation to the status of China as a } \\
\text { WTO member has attracted heated international debates especially with regard to the } \\
\text { expiry of Paragraph 15(d) of the Protocol on the Accession of the People's Republic of } \\
\text { China to the WTO (hereinafter "Accession Protocol"). Many commentators had hoped } \\
\text { that December 2016 would signal the end of the contestations as to whether China is a } \\
\text { market or non-market economy. At the end of 2017, the EU enacted a new anti- } \\
\text { dumping and anti-subsidy legislation aimed at addressing state-induced market } \\
\text { distortion that will undoubtedly reinvigorate the debates on market and non-market } \\
\text { economies at the WTO. The EU practice and the new legislation are yet to be } \\
\text { subjected to extensive academic scrutiny. Although the US has also been at the } \\
\text { forefront of invoking particular market situation ("PMS") in relation to dumping } \\
\text { investigation against imports from China, this paper focuses on China- EU relations } \\
\text { vis-à-vis WTO anti-dumping law. It argues that although paragraph 15(d) of the }\end{array}$ \\
$\begin{array}{l}\text { Accession Protocol might have expired in December 2016, the substantive content of } \\
\text { the concept of NME in the calculation of dumping margin in the EU has not } \\
\text { disappeared. The concept of 'significant distortions' due to state interference, } \\
\text { introduced in the 2017 EU's country-neutral legislation, still allows the EU investigating } \\
\text { authorities to calculate normal value in a manner that disregards domestic prices of the } \\
\text { exporting country. The paper concludes with some remarks on how going forward this } \\
\text { contestation can be settled. }\end{array}$ \\
\hline \begin{tabular}{l} 
Yenkong Ngangjoh-Hodu, LLD \\
\hline Order of Authors:
\end{tabular} & \begin{tabular}{l} 
Tianzhu Han \\
\hline
\end{tabular} \\
\hline
\end{tabular}




\author{
Yenkong Ngangjoh-Hodu* and Tianzhu Han**
}

\begin{abstract}
In recent years, the issue of market economy in relation to the status of China as a WTO member has been at the top of heated international debates especially with regard to the expiry of Paragraph 15(d) of the Protocol on the Accession of the People's Republic of China to the WTO (hereinafter "Accession Protocol"). Many commentators had hoped that December 2016 would signal the end of the contestations as to whether China is a market or non-market economy. At the end of 2017, the EU enacted a new anti-dumping and anti-subsidy legislation aimed at addressing state-induced market distortion that will undoubtedly reinvigorate the debates on market and non-market economies at the WTO. The EU practice and the new legislation are yet to be subjected to extensive academic scrutiny. Although the US has also been at the forefront of invoking particular market situation ("PMS") in relation to dumping investigation against imports from China, this paper focuses on China- EU relations vis-à-vis WTO anti-dumping law. It argues that although paragraph 15(d) of the Accession Protocol might have expired in December 2016, the substantive content of the concept of NME in the calculation of dumping margin in the EU has not disappeared. The concept of 'significant distortions' due to state interference, introduced in the 2017 EU's country-neutral legislation, still allows the EU investigating authorities to calculate normal value in a manner that disregards domestic prices of the exporting country. The paper concludes with some remarks on how going forward this contestation can be settled.
\end{abstract}

\title{
I. Introduction
}

1. On 10th July 2017, a WTO panel was composed to hear the dispute between China and the EU regarding some of the EU's regulations on the calculation of dumping margin against Chinese imports. ${ }^{1}$ This was after a consultation requested on the 12th of December, 2016 by China had failed to resolve the dispute. ${ }^{2}$ More specifically, China complained that certain provisions of EU and US laws pertaining to classification of China as a 'non-market economy'

\footnotetext{
*Professor and Chair of International Economic Law, The University of Manchester School of Law. Contact: yenkong.ngangjohhodu@manchester.ac.uk

** Dr. Tianzhu Han is Assistant professor in Shandong University of Science and Technology, China.

Contact: hanxiao6881@163.com

1 Accordingly, the panel was established by the Dispute Settlement Body on 03 April 2017 and composed by the WTO DG pursuance to DSU Article 8.7 on the 10 of July 2017. See WT/DS516/10. On the basis of the communication from the panel hearing the case, the panel report will not be issued before July 2018. See WT/DS516/11 (11 December 2017).

2 DS516, European Union-Measures Related to Price Comparison Methodologies. As of the $4^{\text {th }}$ of September 2017, consultation was still ongoing between China and the US regarding similar measures by the US. See DS515: United States- Measures Related to Price Comparison Methodologies.
} 
("NME"), for the purpose of the determination of dumping margins, were inconsistent with the obligations of the respondents under the GATT/WTO rules. ${ }^{3}$ The request for the establishment of the panel came after the parties had failed to reach an agreement to reclassify China as a market economy in the WTO. ${ }^{4}$ The EU, US and other WTO members had prior to 2001, classified a number of socialist countries including China as a NME. In the case of China this status, which permits WTO members under certain conditions to use prices in third country markets when investigating antidumping, had been understood to last for a maximum of fifteen years from the date of China's accession to the WTO. ${ }^{5}$

\section{At issue in the EC-Measures Related to Price Comparison Methodologies and the US-Measures Related to} Price Comparison Methodologies cases is the methodology employed by the EU and the US in the calculation of dumping margin which continued to regard China as a NME. ${ }^{6}$ It is obviously tempting to think that the ruling of the WTO Dispute Settlement Body, whichever way it will go in this case, would settle the issue of whether China is a market or a non-market economy. While the ruling will provide some clarity as to the subject, finally resolving the issue may still need the EU, the US and China to come up with some imaginative approach to implement the report and clarify some of the issues relating to the notion of market and non-market economy in WTO antidumping law. ${ }^{7}$

3. This article starts by analysing the origin of China's market economy status dilemma and EU's approach in classifying China as a NME country. It further examines Paragraph15 of the Accession Protocol of China, as well as certain WTO jurisprudence in relevant cases, in order to shed some lights on how the issue of China market economy status may be resolved going forward. The paper further argues that although paragraph 15 of the Accession Protocol might have expired in December 2016, the substantive content of the concept of NME in the

\footnotetext{
3 When China acceded to the WTO in 2001, it was classified as a non-market economy. This allowed other WTO Members to be able to essentially ignore domestic prices in China when determining whether dumping has occurred by comparing the export price with the domestic price of a third party market. However, Paragraph 15 of China's Protocol of Accession opened the possibility of this status lapsing fifteen years later. On the basis of this, the EU and the US should have started considering China as a market economy as from December 2016.

4 Paragraph 15 (d) of the Accession Protocol of China in relevant parts states “... [th] provisions of subparagraph (a)(ii) shall expire 15 years after the date of accession. In addition, should China establish, pursuant to the national law of the importing WTO Member, that market economy conditions prevail in a particular industry or sector, the non-market economy provisions of subparagraph (a) shall no longer apply to that industry or sector." See Accession of the People Republic of China, Decision of 10 November 2001, WT/L/432, (23 November 2001).

5 See Jean-François Bellis's presentation at the Workshop on "Market Economy Status for China after 2016?” organised by the European Parliament, Brussels, (28 January, 2016), Katarzyna Kaszubska, Rethinking China's Non-Market Economy Status Beyond 2016, ORF Occasional Paper No.107 (JANUARY 2017).

6 WT/DS515/1; WT/DS516/1.

7 Dispute Settlement Understanding (DSU) Article 3.7 encourages WTO members to seek mutually acceptable solution to disputes.
} 
calculation of dumping margin in the EU has not disappeared. The concept of 'significant distortions' due to state interference, introduced in the 2017 EU's country-neutral legislation, still allows the EU investigating authorities to calculate normal value away from using domestic prices of the export country.

\section{China's Market Economy Status dilemma-Where does it come from?}

1. When China joined the WTO in 2001, special provisions in determining price comparability in anti-dumping investigations were adopted. Paragraph 15(a) and (d) of the Accession Protocol allows the WTO members to apply special NME methodologies when they investigate import from China in their antidumping laws.

2. However, it is important to note that although the multilateral trading system is based on market economy principles, there is no provision in the WTO defining what a market or a NME is. Neither Article VI of GATT 1994 nor WTO Agreement on Antidumping contain any definition or distinction between a market economy and a NME. These two terminologies are only grounded in the municipal laws of a few W'TO members. ${ }^{8}$

3. The NME problem can be traced back to the cold war period, when western countries initiated special trade treatment towards communist/socialist countries. Such treatment was mainly due to state monopoly in all sectors of the economy in such countries. ${ }^{9}$ It became prominent in the multilateral trading system, during the negotiations of the failed International Trade Organization ("ITO"), in anticipation of Russia's membership. ${ }^{10}$ As the ITO was never realized, the issue of state trading enterprises or NME was initially abandoned and was only brought back into the multilateral forum in 1955, during the GATT Review Session. ${ }^{11}$ As a consequence, Ad Note to Article VI:1 was added to GATT 1947 and then, carried forward to GATT 1994. The Ad Note reads; "[i]t is recognized that, in the case of imports from a country

8 For an analysis on some WTO member's law on the concept of Market and NME, see Laura Puccio, Granting Market Economy Status to China: An analysis of WTO law and of selected WTO members' policy, European Parliament Research Service, PE 571.325, November 2015). Available at http://www.europarl.europa.eu/RegData/etudes/IDAN/2015/571325/EPRS_IDA(2015)571325_E N.pdf (accessed, September 2017).

9 Robert Crawford, Regime Theory in the Post-Cold War World: Rethinking Neoliberal Approaches to International Relations, Dartmouth Publishing, 1996. p.53.

10 Russia never became a member though.

11 See Robert E. Hudec, Developing Countries in the GATT Legal System, (CUP, 1987), A comprehensive analysis of this case is given in Robert E. Hudec, The GATT Legal System and World Trade Diplomacy (Butterworth Legal Publisher, 1990), Mary E. Footer, An Institutional And Normative Analysis of the World Trade Organization, (Martinus Nijhoff Publishers, 2006). 
which has a complete or substantially complete monopoly of its trade, and all domestic price are fixed by the state"12, a strict comparison with domestic prices in such a country may not always be appropriate, therefore, flexibility is allowed in terms of normal price determination. Accordingly, certain W'TO members, notably the US and EU developed special treatment in targeting those countries, i.e. third country methodology and single rate method. The special treatment is also codified in WTO accession protocols of several formal socialist countries including that of China. ${ }^{13}$ Therefore, consistent with the provision, WTO members may deviate from the requirement of Article 2.1 of the Agreement on antidumping when calculating the margin of dumping in the case of centrally planned economies ("CPE") ${ }^{14}$ by using third country price or analogue country methodology.

\section{II.1 The Concept of NME in the EU municipal Law}

1. As indicated above, the concept of NME is not per se, a legal terminology in GATT/WTO law. It is a terminology that has only been codified in some WTO Members' legislations and policies. The United States for instance, defines non-market economy as "any foreign country that does not operate on market principles of cost or pricing structures, leading to sales that do not reflect a product's fair value."15 Although China has for a long time been treated as a NME in EU antidumping practice, NME does not have a concrete definition within EU law. Relevant EU legislations only contain a somewhat non-exhaustive list of countries that are regarded as NME. ${ }^{16}$ This list contained some former Eastern European countries that have long graduated and are also currently EU member states. ${ }^{17}$ In this regard, the EU has enacted many regulations relating to state trading enterprises. However, it was only in 2008, following numerous requests by China to be classified as a market economy that the Commission came up with five criteria that China would have to fulfil in order to be reclassified as a market economy. ${ }^{18}$ To summarise, NME is an

\footnotetext{
12 See Ad Note 1(2) to Article VI of GATT 1994.

13 See also US-Vietnam WTO-Coalition on Vietnam's designation as a NME by the US, USTR, http://www.usvtc.org/trade/wto/coalition/WTOCoalition-FactsheetNME27Jul06.pdf (accessed September 2017).

14 The concept of CPE was used until early 1990s to refer to countries where economic activities "were based on yearly plans usually elaborated by a body like state planning commission". These countries were mostly Central and Eastern European, USSR, China, Vietnam etc. See Walter Goode, Dictionary of Trade Policy Terms, $4^{\text {th }}$ ed, (CUP, 2003), p. 57.

15 See Evaluation of China's Non-market Economy Status, US-China Economic and Security Commission, Issue Brief, (18 April, 2017), citing Tariff Act of 1930, Pub. L. No. 103-465, 1930, Codified at 19 U.S.C, $\int 1677(18)$.

16 Council Regulation (EC) No 1225/2009 of 30 November 2009 on protection against dumped imports from countries not members of the European Community.

17 The first regulations dealing with issue of NME was Regulation 109/70 of 19 December 1969 establishing common rules for imports from state-trading countries (covering Bulgaria, Hungary, Poland, Romania, Czechoslovakia and USSR). China was included in the amended Regulation in 1978. 18 See Commission Staff Working Document on progress by the People's Republic of China towards graduation to market economy status in trade defence investigations, 19/09/2008, SEC (2008) 2503
} 
economy where "prices and costs are artificially low and hence do not reflect normal market forces. Therefore, for non-market economies, domestic prices are not used as a benchmark against which to compare export prices". ${ }^{19}$

2. As can be seen from the foregoing, the determination as to whether a particular WTO member is a NME or not seems to hinge on how the EU legislation or policy on NME or state trading enterprises is drafted. While the manner in which Paragraph 15 (d) of the Accession Protocol is interpreted is key in the determination of China's NME/market economy status, EU practice seems to provide essentially, an unquestionable flexibility to the Commission to impose duties on Chinese imports. Recently, in a DSU Article 21.5 compliance panel, the Appellate Body upheld most of the panel findings relating to a dispute brought by China regarding EU approach to the calculation of dumping margin against Chinese iron and steel products. ${ }^{20}$ And by the end of 2013, 62\% of all EU anti-dumping measures were against China. ${ }^{21}$ Weijia in a 2013 article shows how the negative effects of anti-dumping measures extend beyond the obvious loss of revenue. ${ }^{22}$ That loss in revenue resulted in a fall in $\mathrm{R} \& \mathrm{D}$ for instance, having productivity implications for the NME. Overall, as a consequence of China's status as a NME, China was subject to 19.4\% of the world's anti-dumping investigations between 1995 and 2008. ${ }^{23}$

3. For instance, in the dispute concerning Colour Television Receivers from China, identical TVs were exported to the US market by companies in Malaysia and China. The Chinese TVs had 78\% of duties imposed, the Malaysians none. As a NME, the US ascertained the normal value of the Chinese product by using India as a surrogate. ${ }^{24}$ Discriminatory terms were seen as necessary "in order [for established WTO members] not to be challenged by transition economy newcomers under the WTO system." 25 The idea that China is different remains today and it "is being used to justify limitless discretion" when it comes to antidumping and countervailing measures. ${ }^{26}$ In

final, p. 6. A revision on these criteria in 2011 found that only one of the five criteria was met by China, i.e., no state intervention in companies linked to privatization. See European Parliament, Policy Briefing, Trade and Economic Relations with China in 2013, p. 24.

19 European Commission - Fact Sheet, Brussels, (13 January 2016), available at http://europa.eu/rapid/press-release MEMO-16-61 en.htm (accessed, September 2017).

20 Appellate Body Report, European Communities — Definitive Anti-Dumping Measures on Certain Iron or Steel Fasteners from China, WT/DS397/AB/R, (adopted, 12 February, 2016).

21 Commission Staff Working document: 33 $3^{\text {rd }}$ Annual Report from the Commission to the Council and the European Parliament on the EU's Anti-Dumping, Anti-Subsidy and Safeguard Activities SWD(2015) 149, final, Brussels.

22 Weijia Rao, China's Market Economy Status Under W'TO Antidumping Laws After 2016, Tsinghua China Law Review, Vol. 5, (2013).

23 See Rui Pan, China's WTO Membership and the Non-Market Economy Status: discrimination and impediment to China's foreign trade, Journal of Contemporary China, Vol. 24, No. 94 (2015), p. 748

24 See Weijia Rao, China's Market Economy Status Under W'TO Antidumping Laws After 2016,

Tsinghua China Law Review, Vol. 5, (2013), P. 154.

25 Page 3 Poletkov

26 K. William Watson, Will Non-market Economy Methodology Go Quietly into the Night? 
other words, the benchmark in determining "market economy status" is only subject to the discretion of the individual WTO members.

4. The evolution of regulations adopted by the EU ${ }^{27}$ shows that the EU legislative body reframed the NME lists constantly. The EU granted full market economy status to Russia and Ukraine in $2002^{28}$ and $2005^{29}$ respectively, while alternative calculation method, i.e. cost adjustment method, was built in the normal value provision, which lead to contentious disputes from then on. As to China's position in EU anti-dumping regulation, a conditional market economy status has been granted to individual producers upon their voluntary application in 1998 (the MET application). Such method remained active until the new regulation ${ }^{30}$ was enacted in 2017.31

5. In DS405, China asserted that at the time of the original investigation, the Commission only examined the MET applications of companies selected for the sample of Chinese exporting producers, and never examined the MET applications submitted by non-sampled cooperating Chinese exporting producers. The non-sampled companies had no chance of receiving any disclosure regarding the results of their MET applications. ${ }^{32}$ The Panel found in favour of the EU and stated that Article 2.4 of the ADA does not establish any requirements with respect to either sampling, or the establishment of normal value. China failed to demonstrate how Article 2.4 regulates MET applications or the use of sampling in examining MET applications. ${ }^{33}$ The

U.S. Antidumping Policy toward China after 2016, Cato Institute Publication No 763, (October, 2014), p. 3

2720 countries were listed as State-Trading Countries under the EU's previous regulation (Council Regulation (EC) No 519/94, OJ L 67, 10.3.1994). The State-Trading Country list was renamed as Non-Market Economy Country list in 1996 (Council Regulation (EC) No 384/96, OJ L 56, 6.3.1996). Several countries have been taken off from the list either based on accession in the EU (i.e. Estonia, Latvia, Lithuania) or specific recognition (Russia and Ukraine). See: Council Regulation (EC) No 905/98, OJ L 128, 30.4.1998; Council Regulation (EC) No 1972/2002, OJ L 305, 7.11.2002; Council Regulation (EC) No 2117/2005, OJ L 340, 23.12.2005.

28 Ibid, Council Regulation (EC) No 1972/2002, OJ L 305, 7.11.2002

29 supra note 27, Council Regulation (EC) No 2117/2005, OJ L 340, 23.12.2005

30 See The EU's new trade defence rules and first country report, European Commission - Fact Sheet, (20 December 2017). Available at http://europa.eu/rapid/press-release_MEMO-17-5377_en.htm

31 while based on the regulation 1225/2009, China was not listed in the conditional market economy treatment list. It seems that China had graduated from the NME list, similar to what the EU did in the cases of Russia and Ukraine. However, the Corrigendum re-listed China and Vietnam in 2010, imposed the conditional treatment to Chinese producers.

32 WT/DS405/R, Panel Report. China asserts independent violations of Article 2.4, 6.10.2, and 17.6(i) of the ADA, Paragraph 15(a)(ii) of China's Accession Protocol, and Paragraphs 151(e) and (f) of China's Working Party Report. China asserted that the EU practice was in violation of paragraph 15(a)(ii) of AP and Paragraphs 151(e) and (f) of the Working Party Report, which requires importing WTO Members to "provide Chinese producers and exporters a full opportunity for the defense of their interests in a particular case." See: para. 7.168.

33 Ibid, para.7.189. 
same reasoning has also been used in Panel's determination of whether Paragraph 15(a)(ii) constitutes a legal basis in challenging EU's practice. ${ }^{34}$ The Panel stated that, in order to challenge EU's practice, China needs to demonstrate that sampling is prohibited for purposes of making the MET determination, and the criteria on which the sample was selected were unjustified. ${ }^{35}$ DS405 reaffirmed EU's discretion in determining MET criteria, as well as in selecting the surrogate country.

\section{II.2 Interpreting Paragraph 15 of Accession Protocol}

1. For the purpose of understanding how going forward the status of China in the WTO may be viewed, we briefly look at the Paragraph that until December 2016 underlined China's status as a NME. The relevant parts of Paragraph 15 are therefore reproduced below.

Subparagraph (a)(ii) of this Paragraph reads:

"[t] he importing WTO Member may use a methodology that is not based on a strict comparison with domestic prices or costs in China if the producers under investigation cannot clearly show that market economy conditions prevail in the industry producing the like product with regard to manufacture, production and sale of that product". Subparagraph (d) provides for conditions under which subparagraph (a)(ii) becomes inapplicable. The subparagraph in its entirety reads:

"Once China has established, under the national law of the importing WTO Member, that it is a market economy, the provisions of subparagraph (a) shall be terminated provided that the importing Member's national law contains market economy criteria as of the date of accession. In any event, the provisions of subparagraph (a)(ii) shall expire 15 years after the date of accession". In addition, should China establish, pursuant to the national law of the importing WTO Member, that market economy conditions prevail in a particular industry or sector, the non-market economy provisions of subparagraph (a) shall no longer apply to that industry or sector."

2. The chapeau of Paragraph 15(a) ${ }^{36}$ read together with subparagraph (a)(ii) permits the investigating authority of an importing WTO member to ignore domestic prices or cost in China and to use a methodology that is based on price comparison in a surrogate market or third party market. However, to the extent that producers under investigation can demonstrate that market economy conditions exist in the domestic industry producing like products, the third party or surrogate market methodology will not be applied. In other words, the NME methodology will not be used. This subparagraph has essentially been the core of China's non-market economy status since China acceded to the WTO in 2001.

34 Ibid, para.7.197.

35 Ibid para.7.201.

36 The chapeau reads; "Article VI of the GATT 1994, the Agreement on Implementation of Article VI of the General Agreement on Tariffs and Trade 1994 ("Anti-Dumping Agreement") and the SCM Agreement shall apply in proceedings involving imports of Chinese origin into a WTO Member consistent with the following:...." 
3. Paragraph 15(d) on the other hand, contains an expiration clause to Paragraph 15(a)(ii) after fifteen years of China's membership to the WTO. In this regard, the subparagraph suggests that China should no longer be classified as a NME as from 12th December, 2016.37 While China continues to insist that it had graduated from its NME status to a market economy as of 12th December, 2016; there have been conflicting interpretations of this subparagraph. One interpretation of Paragraph 15(d) holds that the expiration of subparagraph 15(a)(ii) only means that NME may not apply in all cases. In other words, market economy shall apply to the extent that a Chinese exporter can demonstrate that it conforms to the criteria for market economy within the internal laws of the importing country. Such internal law containing criteria for NME should have existed by the $11^{\text {th }}$ of December, 2001 when China joined the WTO. ${ }^{38}$ The second view interprets the provision as meaning that the burden of proving the existence of NME with regard to a particular Chinese exporter will be on domestic producer in the importing country. ${ }^{39}$ In this regard, the burden of proof is on a particular EU importer in question. Similarly, some other interpretations firmly concur with the view that subparagraph 15(a)(ii) automatically expired on 12th December, 2016.40This latter approach seems plausible if one is to go by the following sentence under subparagraph 15(d) that states "In any event, the provisions of subparagraph (a) (ii) shall expire 15 years after the date of accession". This means that in no other circumstances post December 2016 would subparagraph 15(a)(ii) or second Ad Note 2 to GATT Article VI.1 apply with regards to anti-dumping investigation concerning Chinese imports into the EU.

$37 \mathrm{WT} / \mathrm{L} / 432$ at p. 9.

38 European Parliament, Workshop: Market Economy Status for China after 2016? (2016), available at: http://www.europarl.europa.eu/RegData/etudes/STUD/2016/535023/EXPO_STU(2016)535023_ EN.pdf (accessed on 1 May 2017); Joris Cornelis, 'China's Quest for Market Economy Status and its Impact on the Use of Trade Remedies by the European Communities and the United States' Global Trade and Customs Journal, Vol. 2, Issue 2, (2007), pp. 105-115; Barbara Barone, One year to go: The debate over China's market economy status (MES) heats up, Directorate-General for External Policy, European Parliament document: DG EXPO/B/PolDep/Note/2015_330 (2015), pp. 12-13, available at: http://www.europarl.europa.eu/RegData/etudes/IDAN/2015/570453/EXPO_IDA(2015)570453_ EN.pdf (accessed September 2017).

39 See Jorge Miranda, Interpreting Paragraph 15 of China's Protocol of Accession, Global Trade \& Custom Journal, Vol. 9, Issue 3, (2014), pp. 94-103, See also interesting comment on the same by Theodore R. Posner, A Comment on Interpreting Paragraph 15 of China's Protocol of Accession, Global Trade \& Custom Journal, Vol. 9, Issue 4, (2014), pp. 146-153.

40 Weijia Rao, China's Market Economy Status Under WTO Antidumping Laws After 2016, Tsinghua China Law Review, Vol. 5, (2013), pp. 151-168, Matthew R. Nicely, Time to Eliminate Outdated Non-Market Economy Methodologies, Global Trade \& Customs Journal Vol. 9, Issue 4, (2014), pp. 160164; Bernard O'Connor, Much Ado About Nothing': 2016, China and Market Economy Status, 10(5) Global Trade \& Customs Journal, Vol. 10, Issue 5, (2015), pp. 176-180. 
4. 11 out of 15 disputes brought by China before the WTO DSB have targeted trade remedy laws in the US and EU, among which, four cases ${ }^{41}$ cited Paragraph 15 of the Accession Protocol, and two of them were brought up before the DSB based on Paragraph 15(d).42 It is worth to explore to what extent subparagraph (a)(ii) is distinct from general WTO law, and whether the expiry of such subparagraph completely brings this distinction to an end.

5. With regards to the issue of the place of subparagraph (a)(ii) within the WTO law, it is worth revisiting the general WTO legal architecture in terms of determining normal value of products as stipulated in GATT Article VI:1 and ADA Article 2. As discussed above, both of these provisions state that normal value is a "comparable price, in the ordinary course of trade". ${ }^{43}$ In defining "comparable prices", Article 2.2 ADA enumerates three other acceptable scenarios where no proper comparison is available. ${ }^{44}$ Article $2.3 \mathrm{ADA}$, the first and second Ad Notes to Article VI:1 go one step further in explaining the more detailed situation where comparable price shall be determined other than domestic prices. Article 2.3 recognises that export price may need to be "constructed on the basis of the price at which the imported products are first resold to an independent buyer" when "export price is unreliable because of association or compensatory arrangement between exporter and importer or a third party", which emphasizes the importance of independence between buyer and seller. ${ }^{45}$ In this regard, the Second $A d$ Note to GATT Article VI:1 recognises that, "in the case of imports from a country which has a complete or substantially complete monopoly of its trade and where all domestic prices are fixed by the State,... importing contracting parties may find it necessary to take into account the possibility that a strict comparison with domestic prices in such a country may not always be appropriate." It is hence indicated that comparable prices "in the ordinary course of trade" shall be market-determined, reflecting arm's-length transactions between buyer and sellers. ${ }^{46}$ Investigating authorities of contracting parties therefore, have the obligation to prove that their decisions of not using domestic price are well grounded under the previous provisions, otherwise, domestic price shall be deemed as "comparable", and that no other proxy is available or subject to the determination of dumping comparison.

\footnotetext{
41 Against EU: DS397 and DS405; against the US: DS379 and DS 437.

42 DS515 and DS516.

43 GAT'T VI:1 and Article 2.2 ADA. (cite different expressions)

44 ADA Article 2.2 says: "When there are no sales of the like product in the ordinary course of trade in the domestic market of the exporting country or when, because of the particular market situation or the low volume of the sales in the domestic market of the exporting country,..."

45 First Note Ad Article VI:1 also states that "the sale by an importer at a price below that corresponding to the price invoiced by an exporter with whom the importer is associated..., the margin of dumping may be calculated on the basis of the price at which the goods are resold by the importer."

46 Appellate Body Report in US-Hot Rolled Steel, para.142, AB states that a price for a sale may not reflect the criteria of the marketplace, such as profit-maximization.
} 
6. As indicated above, Paragraph 15(a) of Accession Protocol is comprised of its chapeau and subparagraphs (a) (i) and (a) (ii). The chapeau of Paragraph 15(a) indicates that there are two options for investigating authorities in determining price comparability under GATT Article VI and ADA. In terms of whether domestic prices of China should be used to calculate a normal value for comparison or not, the chapeau per se, is an introductory provision which may not be deemed as creating a separate obligation on a WTO member. ${ }^{47}$ The two options are respectively reflected under subparagraphs (a)(i) and (a)(ii).

7. Pursuant to subparagraph (a)(i), importing WTO members shall use Chinese prices or costs to determine price comparability; provided that Chinese producers under investigation can clearly show market economy conditions prevail in the 'like product' industry. Once Chinese producers fail to prove the above criteria, non-Chinese prices or costs shall be available for importing members according to subparagraph (a)(ii). The two subparagraphs clearly allocate the burden of proof on Chinese producers in every investigation that is initiated by importing members. The above options are the only two choices that are available to importing members. Yet, their scope of application does not overlap with each other. ${ }^{48}$ Once subparagraph (a)(ii) expires, the second option, namely, to use non-Chinese prices and costs in price comparison, shall no longer be available for any importing member. Therefore, according to Paragraph 15(d), 12th December, 2016 shall be the termination date for the second option. In other words, going forward, non-Chinese prices and costs shall not be a choice for the determination of normal value.

8. Some commentators argue that, even if subparagraph (a)(ii) expired, China would still have to meet the criteria set forth by the individual importing member in order to qualify for a market economy status. ${ }^{49}$ The foregoing view tends to stress the wording of the chapeau and subparagraph (a)(i), contending that the ongoing effectiveness of the other parts of paragraph 15 is sufficient for the continued labelling of China as a NME. The burden of proof, according to

47 The structure of Paragraph 15 indicates that there is no independent right conferred by the Chapeau, hence, it cannot be operated independently. It is different from the chapeau of Article 2.2.2 of the ADA and Article XX of the GATT 1994, as both of them entail specific obligations that Members have to comply with. See: Minyou Yu, and Jian Guan, "The Non-Market Economy Methodology Shall be Terminated After 2016”, (2017) 12 Global Trade and Customs Journal, Issue 1, pp.16-24.

48 Id. Weihuan Zhou (2017), The author describes the two subparagraphs as "two sides of one coin".

49 Terence Stewart et al, "The Special Case of China: Why the Use of a Special Methodology Remains Applicable to China After 2016", (2014) 9 Global Trade and Customs Journal, Issue6, pp.272-279; Jorge Miranda, "More on Why Granting China Market Economy Status after December 2016 is Contingent upon Whether China Has in Fact Transitioned into a Market Economy" (2016) 11 Global Trade and Customs Journal, Issue 5, pp.244-250; Paul C. Rosenthal, Jeffrey S. Beckington, "The People's Republic of China: A market Economy or Non-Market Economy in Anti-Dumping Proceedings Starting on December 12, 2016?" (2014) 9 Global Trade and Customs Journal, Issue 7/8, pp.352-355. 
this view of a market economy condition, would continue to rest on Chinese exporters. ${ }^{50}$

9. Central to the arguments against China's market economy status post 2016, is the fact that subparagraph (a)(ii), which should have expired in 2016 is not the one that gives members the right to treat China as a NME; it rather allows members, recourse to NME methodology by default. ${ }^{51}$ Accordingly, members' right to rely on NME assumption is embedded in chapeau of subparagraph (a)(i) as well as subparagraph (d). The wording of the second sentence of paragraph 15(d) provides for the expiry of subparagraph 15(a)(ii) instead of Paragraph 15(a) as a whole. Hence, the expiration did not affect members' right to apply NME assumption, it just terminates members' right to use surrogate price when "producers under investigation cannot clearly show that market economy conditions prevail...”. As long as China's whole economy, or individual industry or sector remains NME, according to importing member's domestic criteria in determining market economy status; NME assumption is still in the hands of importing members. ${ }^{52}$

10. Treaties usually represent compromise between contracting parties. The WTO Treaty system is no different. Therefore, just like any other treaty, the Accession Protocol and in particular, Paragraph 15 raises some interpretative issues. Interpreting Paragraph 15 in light of the Vienna Convention ("VCLT") 53 , the above arguments that advocate for continuous application of NME status on Chinese products seems incongruous with the spirits of Paragraph 15(d) for the following reasons:

10.1. First, according to VCLT Article 31(1), the following must be at the centre of treaty interpretation, namely; 'ordinary meaning of terms', 'good faith' 'context' and 'object and

\footnotetext{
50 Jorge Miranda, "Implementation of the 'Shift in Burden of Proof' Approach to Interpreting Paragraph 15 of China's Protocol of Accession” (2016) 11 Global Trade and Customs Journal, Issue 10, pp.447-453.

51 Jorge Miranda, “A comment on Vermulst's Article on China in Anti-dumping Proceedings After December 2016" 11 Global Trade and Customs Journal Issue 7/8, pp.306-313.

52 In supporting such argument, paragraph 150 of the Working Party Report is frequently quoted by scholars. They contend that such paragraph denotes China was in a process of transition towards a market economy, and such transition justified other importing members to use NME method in the calculation of normal value. Importing members' domestic law sets forth the criteria in recognizing China's transition. As subparagraph (d) did not set the cut-off date to recognize China as a market economy for importing members, the justification of NME Assumption remains intact after 2016. See: Jorge Miranda, Implementation of the 'Shift in Burden of Proof' Approach to Interpreting Paragraph 15 of China's Protocol of Accession", supra note. 77.

53 Rules for Treaty Interpretation from the Vienna Convention on the Law of Treaties, signed at Vienna, 23 May 1969: UN Doc A/Conf39/28. Vienna Convention was endorsed by WTO tribunals in interpreting WTO agreements. The Appellate Body has acknowledged that the interpretative methodology set out in Article 31 and 32 of the Vienna Convention "has attained the status of a rule of customary of general international law", WTO tribunals are mandated to adhere when interpreting the covered agreements. See: Appellate Body Report, United States_Standards for Reformulated and Conventional Gasoline, WT/DS2/AB/R, 20 May 1996, p.17.
} 
purpose'. Consistent with the 'terms' of the treaty at hand, subparagraph (d) is comprised of three independent sentences. The first and third sentence stipulate that subparagraph (a) shall be terminated as a whole provided that China or particular industry/sector of China fulfils the criteria of market economy under the importing members' national law. The second sentence states that subparagraph (a)(ii) shall expire after 15 years 'in any event'. ${ }^{54}$ According to Oxford English dictionary, "in any event" means "for anything that might happen". ${ }^{55}$ This means that for anything that might happen subparagraph (a)(ii) should have expired in December 2016. As analysed above, the chapeau and subparagraph (a)(i) do not contain any words that convey right to the importing members to use non-Chinese prices or cost. The expiration of subparagraph (a) (ii) means that the application of non-Chinese prices or cost is no longer possible on the basis of paragraph 15. The contention that the expiration of subparagraph (a)(ii) means that importing members shall no longer apply non-Chinese prices and cost automatically, but it does not terminate the right of application; seems inconsistent with the original text. The primacy of the text in interpretation is well recognised by international tribunals and is now uncontested in WTO jurisprudential progressivism. ${ }^{56}$ It is widely recognised that interpretation must be firmly rooted in the text of the treaty in question. ${ }^{57}$ In this regard, had negotiators intended to continue the application of non-Chinese prices and costs, they could have perhaps specified unequivocally so, in the chapeau or subparagraph (a)(i). It may therefore be submitted that to the extent that a particular right or obligation does not form an express part of a treaty, an interpreter would be estopped from reading the treaty in a way that may add or subtract such right or obligation. ${ }^{58}$

10.2. Second, international tribunals tend to stress the fundamental importance of 'good faith'59 in treaty interpretation. ${ }^{60}$ Good faith applies to the whole process of interpreting a treaty rather

\footnotetext{
54 It is one of the strongest terms to mandate certain action without any exception. Such expression leaves no room or possibility for the importing members to manipulate the interpretation of the expiration affect of subparagraph 15(a)(ii).

55 See Oxford English Dictionary, (2018). Available at https://public.oed.com/the-oed-today/recent-updates-to-the-oed/ (Visited on 16 March 2016). 56 As pointed out by the AB in US - Carbon Steel, "...the task of interpreting a treaty provision must begin with its specific terms...”. See AB Report, WT/DS213/AB/R, para. 62, AB Report, EC Hormones, para. 181, AB Report, US — Softwood Lumber IV, para. 59 etc.

57 International tribunals have usually rejected otherwise reasonable interpretations because to accept them would have been tantamount to rephrasing or otherwise altering the actual text. See: Richard Gardiner, Treaty Interpretation, Second Edition, Oxford University Press, 2009.

58 "Sometimes the absence of something means simply that it is not there". See: Appellate Body Report, Canada_Term of Patent Protection, WT/DS170/AB/R (2000), para.78. Also see: Richard Gardiner (2009), p.165.

59 According to the definition of good faith in Black's Law Dictionary, "Good faith' performance or enforcement of a contract emphasises faithfulness to an agreed common purpose and consistency with the justified expectations of the other party; it excludes a variety of type of conduct characterized as involving 'bad faith' because they violate community standards of decency, fairness and reasonableness." Bryan A. Garner, Black’s Law Dictionary, West Group, 701, (1999) (hereinafter, Garner).

60 See: John F. O’Connor, Good Faith in International Law, Dartmouth: Aldershot, 1991.
} 
than solely to the meaning of particular words or phrases of the text. ${ }^{61}$ Although subjective in explaining the content of good faith, it is commonly related to the principle of effectiveness and reasonableness whose interpretation may be linked to the history and preparatory work, the context, as well as the object and purpose of the treaty. ${ }^{62}$ In addition, good faith requires the balancing of treaty elements when interpreting. ${ }^{63}$

10.3. Moreover, despite the contestation regarding the expiration of China NME status, many commentators have put forward compelling arguments in support of the 2016 expiration deadline based on paragraphs 150 and 151 of the Report of the Working Party on the Accession of China (Working Party Report). ${ }^{64}$ Paragraph 151 clearly expresses that when applying NME methodology, as stipulated under subparagraph 15(a)(ii), a WTO member with municipal law on NME at the time of China accession must follow strict criteria identified under paragraph 151 (a-f). It can be seen that subparagraph (a)(ii) is the only legal ground for NME status. Both paragraph 15 of Accession Protocol and the Working Party Report are supplementary rules to GATT Article VI and the ADA, when it comes to price comparison during China's transition period. Moreover, paragraph 151 further demonstrates the common intentions of the parties which must 'add colour, texture and shading'65 to any interpretation of paragraph 15 of the Accession Protocol. ${ }^{66}$ Thus, paragraph 15 is a time-bound provision whose operation terminated in 2016. In view of the well-known principle of effectiveness in treaty interpretation, to the extent that the EU and the US continue to use the surrogate country post-2016 in the

61 Richard Gardiner (2009), p.168. As was pointed out by the WTO AB in one of its early report

"... [P] erformance of treaties is also governed by good faith. Hence, Article 26 of the Vienna

Convention, entitled Pacta Sunt Servanda, to which several appellees referred in their submissions (foot note omitted), provides that '[e]very treaty in force is binding upon the parties to it and must be enforced by them in good faith'(foot note omitted). Clearly therefore, there is a basis for a dispute settlement panel to determine, in an appropriate case whether a Member has not acted in good faith" See Appellate Body Report, United States - Continued Dumping and Subsidy Offset Act of 2000, adopted January 27, 2003, W'T/DS217/AB/R, WT/DS234/AB/R, paras. 296 and 297.

62 Richard Gardiner (2009), pp.172-180, see also Thomas Wilhelmson,'Good Faith and the Duty of Disclosure in Commercial Contracting - The Nordic Experience," in Cottier and Schefer, 53 (2000).

${ }^{63}$ Ngangjoh-Hodu, Pacta Sunt Servanda and Complaints in the WTO Dispute Settlement Manchester Journal of International Economic Law (MJIEL)-Vol. 1, Issue 2, 2004, pp. 76-96 as well as Richard Gardiner (2009), p.178.

64 Report of the Working Party on the Accession of China, Doc WT/ACC/CHN/49 (1 October 2001). Articles analyzing such issue are selected as follows: Zhenghao Li, Interpreting Paragraph 15 of China's Accession Protocol in Light of the Working Party Report, (2016) Global Trade and Customs Journal, 11(5), pp.233-234; Andrei Suse, “'Old Wine in a New Bottle': The EU's Response to the Expiry of Section 15(a)(ii) of China's WTO Protocol of Accession”, KU Leuven Working Paper No.186, May 2017; Jochem de Kok, "The future of EU Trade Defence Investigations against Imports from China"(2016) Journal of International Economic Law, pp.525-528; David Kleimann, "The Vulnerability of EU Anti-Dumping Measures against China after December 11, 2016”, EUI Working Papers RSCAS 2016/37, July 2016.

65 See AB Report in US — Shrimp, WT/DS58/AB/R, para. 153.

66 As has been demonstrated in WTO jurisprudence, “... The purpose of treaty interpretation is to establish the common intention of the parties to the treaty." See AB Report in EC - Computer Equipment, WT/DS62, 67, 68/AB/R, paras. 84 and 93, AB Report, EC — Chicken Cuts, para. 93. 
determination of market price for the purpose of calculating of dumping margin, the effectiveness of the second sentence of subparagraph 15(d) will be undermined. As was reiterated by Lauterpacht in his seminal article titled 'Restrictive Interpretation and the Principle of Effectiveness in the Interpretation of Treaties' ${ }^{67}$, the so-called restrictive interpretation of treaties must be avoided by an interpreter. Such interpretation would be incongruous with the object and purpose of paragraph 15.11. Article 15 of the Accession Protocol has been cited in several WTO disputes brought up by China. ${ }^{68}$ As noted earlier, in EC-Fasteners, the WTO Appellate Body interpreted Paragraph 15(d) of the Accession Protocol. It held that:

"Paragraph 15(d) of China's Accession Protocol establishes that the provisions of paragraph 15(a) expire 15 years after the date of China's accession (that is,11 December 2016). It also provides that other WTO Members shall grant before that date the early termination of paragraph 15(a) with respect to China's entire economy or specific sectors or industries if China demonstrates under the law of the importing WTO Member 'that it is a market economy' or that 'market economy conditions prevail in a particular industry or sector'.'69

11. It can be seen that the Appellate Body's interpretation was in line with the above analysis. The answers to the two questions also become explicit. First, subparagraph (a)(ii) provides legal basis for the importing members to disregard Chinese prices and costs, should Chinese producers fail to prove its market economy status under importing members' domestic law. With regard to the second sentence of paragraph 15(d), the special methodology expired in December 2016 and the importing members may no longer take recourse to subparagraph 15(a)(ii) to justify their application of non-Chinese prices and cost. It is therefore, arguably clear that on the basis of the remaining part of paragraph (a), once China fails to prove market economy criteria under importing members' domestic law, importing members shall only take recourse to general WTO law to find alternative method in calculating normal value.

\section{II.3 Interpretation of NME in the Context of EU law}

1. In terms of the judicial interpretation regarding Art.2(7), the judgment of the ECJ in case European Commission v. Rusal Armenal $Z A O^{70}$ is worth noting. Rusal Armenal ZAO is an Armenian manufacturer and exporter of aluminum products Armenia is a WTO member since 2003. In 2008, the European Communities initiated an antidumping proceeding against certain

\footnotetext{
67 H. Lauterpacht, Restrictive Interpretation and the Principle of Effectiveness in the Interpretation of Treaties, 26 Brit. Y.B. Int'l L. 48 (1949).

68 United States-Definitive Anti-dumping and Countervailing Duties on Certain Products from China, DS379; European Communities-Definitive Anti-Dumping Measures on Certain Iron or Steel Fasteners from China, DS397; United States-Countervailing Duty Measures on Certain Products from China, DS437.

$69 \mathrm{WT} / \mathrm{DS} 397 / \mathrm{AB} / \mathrm{R}$, para. 289.

70 European Commission v. Rusal Armenal ZAO, Judgment of ECJ of 16 July 2015, ECLI:EU:C:2015:494.
} 
aluminum products originating in Armenia, Brazil and China. ${ }^{71}$ Rusal Armenal Zao first brought the case to the General Court, where the company disputed the classification of Armenia amongst the NME countries pursuant to Art.2(7) of Council Regulation No.384/96 ("The Basic AD Regulation"). ${ }^{72}$ In addition, the company submitted a claim to be granted market economy treatment or individual treatment which falls under Art.2(7)(c) should the previous claim fail. In response, the Commission concluded that Armenia could not be regarded as a market economy, as it was listed in the footnote of Art.2(7)(a) of the Basic AD Regulation, and the company did not satisfy the criteria that is contained within Art.2(7)(c). The general court upheld that Art.2(7) of the Basic AD Regulation was contrary to Art.2.7 of the Anti-Dumping Agreement set out in Annex 1A to the Agreement Establishing the WTO, and hence, such provision was annulled in so far as it concerned Rusal Armenal. ${ }^{73}$

2. The case was appealed by the Commission on three grounds: firstly, the General Court had ruled ultra petita; secondly, the General Court had erred in law in holding that Article 2(7) of the basic regulation is intended to implement the particular obligations assumed in the context of the WTO and; thirdly, there had been an infringement of the general principle of institutional balance. ${ }^{74}$ The ECJ upheld the second ground of appeal, and pointed out that given their nature and purpose, WTO agreements are not in principle among the rules, in the light of which the Court is to review the legality of measures adopted by the EU institutions ${ }^{75}$. The exceptions are the following two situations: first, where the EU intends to implement a particular obligation assumed in the context of those WTO agreements, and second, where the EU's acts at issue refer explicitly to specific provisions of those agreements. ${ }^{76}$ Due to the absence of specific rules relating to the method of calculating normal value originated from NME countries in the WTO agreements, the ECJ concluded that Art.2(7) cannot be considered to be a measure intended to ensure the implementation in the EU legal order of a particular obligation assumed in the context of the WTO. ${ }^{77}$

3. Following the logic applied by the ECJ, direct correlation between Art.15 of the Accession Protocol and Art.2(7) of the Basic AD Regulation also cannot be established, as Art.15 only calls for countries to refrain from using strict comparison when Chinese products were under investigation..$^{78}$ The judgment of 4th February, 2016 concerning imports of footwear with

71 OJ 2008 C 177, p.13.

72 OJ 1996 L 56, p.1.

73 T-512/09, EU:T:2013:571.

74 ECLI:EU:C:2015:494.

75 ECLI:EU:C:2015:494, para.37-38.

76 ECLI:EU:C:2015:494, para.40-41.

77 ECLI:EU:C:2015:494, para.49-53.

78 Compare to Procedures for on-the Spot Investigations Pursuant to Paragraph 7 of Article 6 GATT, and Article 2 of ADA, Art.15 of Accession Protocol of China goes one step ahead in clarifying the conditions of using non-strict comparison method in calculating normal value. However, NME was not used in the 
uppers of leather originating in China and Vietnam ${ }^{79}$, further confirmed the ECJ approach in terms of how the ECJ assesses the effects of the W'TO agreements on the legal order of the EU. ${ }^{80}$ In this case, the court pointed out that to accept that the EU judicature has the direct responsibility for ensuring that EU law complies with the WTO agreements would effectively deprive the EU's legislative or executive bodies of the discretion which the equivalent bodies of the EU trading partners' enjoy. ${ }^{81}$ Therefore, the legality of Art.2.7 is not about to be challenged if EU continued to apply NME method to products originating from China after the expiration of Art.15 of the Accession Protocol, as Art.2(7) cannot be considered to be a measure intended to ensure the implementation of a particular obligation contained in Accession Protocol, within the EU legal order. In this regard, resorting to any remedial action through Court of Justice of the European Union (CJEU) would be difficult for Chinese producers.

4. It has been argued that the NME list, and the conditional ME list adopted by the Basic AD Regulation have more political impact rather than legal and economic concern, ${ }^{82}$ if there were any. Different from the previous amendments, after the adoption of the Treaty on European Union and the Treaty on the Functioning of the European Union ("TFEU"), ${ }^{83}$ European Parliament gained co-decision power with European Council according to Art.207(2). ${ }^{84}$ Through "ordinary legislative procedure", the Parliament gained legislative power over almost all EU acts, which covers nearly 80 areas of issues. However, in May 2016, 6 months before the expiration date stipulated in Art.15 of the Accession Protocol, the European Parliament through resolution;

provision, and the detailed rules in calculating were also absent.

${ }_{79}$ C\&J Clark International and Puma, C-659/13 and C-34/14, EU:C:2016:74.

80 A lot has been written on the place of WTO law in EU legal order. See for instance, Marco Bronckers, "The Effect of the WTO in European Court Litigation", Texas International Law Journal 40 (2005), pp. 443-448, Marco Bronckers, "The Relationship of the EC Courts with Other International Tribunals: Non-committal, Respectful or Submissive?”, Common Market Law Review 44 (2007), pp. 601-627, Luca Barani, Relationship of the EU legal order with WTO law: Studying Judicial Activism, GARNET (Working Paper No: 70/09 September 2009), Thomas Cottier, The Implications of EC - Seal Products for the Protection of Core Labour Standards in WTO Law, (Springer, 2018), etc.

81 Id, para.86.

82 Liliana Popescu, "The NME Status of the Republic Moldova and the Market Economy Status of Ukraine and Russia: A Political Decision of the European Union and its Implications within the WTO Legal Framework", 5 Global Trade and Customs Journal 3, 2010, pp.113-119; European Commission, Inception Impact Assessment: Possible change in the methodology to establish dumping in trade defense investigations concerning the People's Republic of China, 10 February 2016; "European Commission Weighs Four 'Mitigating' Steps to Blunt China MES", Inside U.S. Trade, 4 February 2016; Gary Hufbauer and Cathleen Cimino-lsaacs, The Outlook for Market Economy Status for China, Peterson Institute for International Economics, 11 April 2016, available at: https://piie.com/blogs/trade-investment-policy-watch/outlook-market-economy-status-china (accessed on 1 June 2017).

83 OJ C83/140 30.03.2010.

84 Art.207(2) of the TFEU:" The European Parliament and the Council, acting by means of regulations in accordance with the ordinary legislative procedure, shall adopt the measures defining the framework for implementing the common commercial policy." 
which is a non-legislative decision in nature; with an $83 \%$ majority voted against granting China market economy status. ${ }^{85}$ This resolution sent a strong signal to the European Commission and Council that they must not be too hasty in granting China market economy status, as doing so would cost Europe job losses in key industries, such as steel.

5. The resolution adopted by the Parliament indicated that, aside from using or not using the third country method in calculating normal value pursuant to Art.2(7), there was a third way, which is, continue to apply special treatment for Chinese producers. In other words, China remains in the conditional ME list, and Art.2(7)(c) continues to apply in categorizing Chinese individual producers. As for producers who fail to reach the 5 criteria contained in Art.2(7)(c), domestic price continues to be disregarded even though the third country method no longer is an option due to the pressure arising from EU's WTO obligation. Already in a legislative decision adopted in 2001, ${ }^{86}$ the European Council recognised that, considering China was an economy in transition, ${ }^{87}$ the deviation from regular anti-dumping mechanism under the WTO law shall last for 15 years from the date of China's accession. ${ }^{88}$ The legality of such sunset provision may arguably be threatened by the resolution adopted by the Parliament in 2016. Although it can be said that such a non-legislative resolution shall not be interpreted as amending the Council Decision adopted in 2001, the resolution clearly serves as merely a political barrier, while the EU is willing to pay for the cost, even though it is an expensive one.

\section{The New Legislation}

1. The European Commission issued a new proposal regarding the amendment of Basic Anti-Dumping Regulation on 9 November 2016,89 amending the previous methodology on the affirmation of normal value. The NME treatment is no longer mentioned according to the new proposal, whilst a new provision has been proposed to calculate normal value away from using domestic prices of the export country, when "significant distortion" occurs. The European Parliament approved such amendment on 15 November 2017 and a new "country-neutral" methodology was adopted, which replaced the previous NME country list subject to normal

\footnotetext{
85 European Parliament Resolution of 12 May 2016 on China’s Market Economy Status (2016/2667(RSP)).

86 Proposal for a Council Decision establishing the Community position within the Ministerial Conference set up by the Agreement Establishing the World Trade Organization on the accession of the People's Republic of China to the World Trade Organization. OJ C 51E, 26.2.2002.

87 id, para.54.

88 id, para. 55 .

89 European Commission, "Proposal for a Regulation of the European Parliament and of the Council Amending Regulation (EU) 2016/1036 on Protection Against Dumped Imports from Countries not Members of the European Union and Regulation (EU) 2016/1037 on Protection Against Subsidized Imports from Countries not Members of the European Union”, Brussels, 9.11.2016, $\operatorname{COM}(2016) 721$ final.
} 
value examination under new initiated anti-dumping investigations..$^{90}$

2. In the new regulation, the previous Article 2(7) was replaced by a new provision, namely Article 2(6)(a), which spells out exactly how to construct an undistorted value by using benchmarks or data from similar countries when domestic prices were contaminated by significant market distortions. Although for WTO Members normal value is usually based on the domestic prices of the like product, there are circumstances in which normal value shall be constructed on the basis of costs of production and sale reflecting undistorted prices or benchmarks. Constructive normal value is applied when prices or costs are not the result of free market forces because they are affected by government intervention. Relevant considerations have been enumerated in the new regulation, such as, "the fact that the market in question is subject to a policy supervision or guidance of the authorities of the exporting country, the state presence in firms allowing the state to interfere with respect to prices or costs, the existence of public policies or measures discriminating in favour of domestic suppliers or otherwise influencing free market forces, and the access to finance granted by institutions implementing public policy objectives." ${ }^{\prime 1}$

3. In addition to the "market distortion" criteria, the new regulation makes it clear that the new system is only subject to investigations initiated after the entry into force of the amended provisions, while the investigations initiated before shall remain governed by the current disciplines. ${ }^{92}$ A "transition" period was incorporated into the amended regulation, which stipulates that reviews of existing measures should only be applied if the factual circumstances of the exporters have changed to an extent that the current level of measures is shown to be no longer appropriate. If a review is initiated as a result of an objective change in the circumstances of an exporter, the review could still be conducted on the basis of the current methodology if the specific circumstances that led to the application of the current methodology have not changed. ${ }^{93}$

4. The following three major changes were incorporated in the new legislation. First, the five criteria in determining market economy ${ }^{94}$ no longer exist. Instead, once the existence of significant distortion is recognised ${ }^{95}$ in a certain country or a certain sector of the country by the

\footnotetext{
90 The parliament adopted the rules with 554 votes for, 48 against and 80 abstentions. See: http://www.europarl.europa.eu/news/en/press-room/20171110IPR87817/parliament-passes-new-a nti-dumping-rules-to-protect-eu-jobs-and-industry (visited on 28th November 2017)

91 Ibid, Explanatory Memorandum.

92 Ibid.

93 Ibid. Article 11(3).

94 1225/2009, Article 2(7).

95 Among other things, according to the new EU report, an economy is significantly distorted "...when reported prices or costs, including the costs of raw materials and energy, are not the result of free market forces because they are affected by substantial government intervention". See the relevant part of point (b) of Article 2(6a) of the new EU legislation which also lays down conditions that will be taken into
} 
report produced by the Commission, ${ }^{96}$ domestic prices and costs in the exporting country shall be disregarded, and constructed value shall be applied. Accordingly, once China or a sector in China is marked as significantly distorted, Chinese producers shall have no legal ground to argue for the application of their domestic price. Furthermore, the EU industry may rely on the evidence in the report in order to justify the calculation of the normal value. ${ }^{97}$ Compared with the previous five criteria for market economy treatment application, the new method seemingly deprives individual producers the opportunity of applying domestic prices in anti-dumping investigations. ${ }^{98}$ Second, Article (6)(a) paragraph (b) defines significant distortion as prices or costs that are not the result of free market forces because they are affected by substantial government intervention. The European Commission issued a working document elaborating significant distortions in the economy of China, which specified that the elements of assessing includes raw material, energy, land, capital, and labour. ${ }^{99}$ This 465 pages report examines the core features of the current shape and structure of Chinese economy, which include the very concept of a 'socialist market economy' and the rule of Chinese Communist Party in relation to the economy. It further focuses on the provision of land, energy, capital, material inputs and labour in China, with a conclusion that the allocation and pricing of the various factors of production is influenced by the State in a very significant manner. This report also examines a number of key trade sectors, namely, steel, aluminium, chemicals, and ceramics, ${ }^{100}$ and the conclusion of such examination also indicates that various factors of production render significant distortions to the above sectors. ${ }^{101}$ With the guidance of such working document, the Commission is inclined to target China or specific trade sectors of China as significantly distorted. Hence, domestic prices in China may easily be disregarded under EU's anti-dumping investigation. Third, Article (6)(a) specified the detailed methods in which normal value will be calculated when significant distortion occurs. Accordingly, corresponding costs of production and sale in a representative country, undistorted international prices, costs, or benchmarks, and domestic prices provided that they are positively established not to be distorted, are available alternatives for the replacement of domestic prices. It should be noted that, unlike the "surrogate country" methodology, the new legislation stipulates that "normal value shall be constructed

account when considering whether a particular market is significantly distorted. See also the introductory note to the report on China in European Commission Document, SWD(2017) 483 final/2 (20 December 2017).

96 Article 2(6), paragraph C, "the Commission shall produce, make public and regularly update a report describing the market circumstances". The term 'non-market economy' was not mentioned, and no WTO member was explicitly named in the new regulation.

97 Article 2(6) paragraph d.

98 Unless individual producer's domestic costs are positively established not to be distorted with accurate and appropriate evidence, see Article 2(6) paragraph a.

99 European Commission, Commission Staff Working Document on Significant Distortions in the Economy of the People's Republic of China for the Purposes of Trade Defense Investigations, SWD(2017) 483 final/2, Brussels, 20.12.2017.

100 Ibid, p.3. "These sectors have been selected because they are the ones that have featured most in the EU's anti-dumping investigations since the conclusion of the Uruguay Round."

101 Ibid, pp.346-375. 
102 See: European Commission, How to Make An Anti-Dumping Complaint-A Guide, Paragraph 66: "Once the existence of significant distortions for the product concerned is established, the normal value must be constructed on the basis of costs of production and sale reflecting undistorted prices or benchmark, including a reasonable amount of SG\&A and profit."

103 Under Article 2.2 ADA, special circumstances include: "when there are no sales of the like product in the ordinary course of trade in the domestic market of the exporting country", when particular market situation occurred, or when the sales volume in domestic market of the exporting country is low.

104 Article 18.1 ADA: "No specific action against dumping of exports from another Member can be taken except in accordance with the provisions of GATT 1994, as interpreted by this Agreement." 105 Article 2(6)a, paragraph b. 2017/2321 
approach other than strict comparison is stipulated under GATT Article VI:1 and Article 2.2 ADA. GATT Article VI:1 only enables the application of CNV when comparable domestic price is absent, ${ }^{106}$ while Article 2.2 ADA elaborates the reasons why comparable domestic price is absent.

3. The phrase Particular Market Situation is included in the provision, although its scope remains unclear. As has been discussed above, under the W'TO dumping is normally determined by comparing home prices of the exporting country to the export prices. ${ }^{107}$ However, consistent with AD Agreement Article 2.2, in the absence of 'comparable price of the like product when exported to an appropriate third country', dumping may be determined on the basis of production cost in home country 'plus a reasonable amount for administrative, selling and general costs and for profits' when there exist a PMS which may inhibit a proper comparison with export prices. The Ad Note to Article VI:1 further provides the basis for non-strict comparison. However, the application of Ad Note to Article VI:1 is very restrictive. It is only applicable when a market is under complete or substantially complete State monopoly. ${ }^{108}$ In EC-Fasteners, the Appellate Body further clarified that the benchmark of applying Ad Note to Article VI:1 is extremely high. ${ }^{109}$ Accordingly, such note is almost impossible to apply to any transitional economy nowadays. Hence, Ad Note to Article VI:1 provides limited reference to the scope of PMS. It is noted that the WTO jurisprudence mainly focuses on the application of PMS instead of defining the actual scope of the same. Recalling the negotiating history of GATT Article VI and ADA, some commentators have observed that a PMS would arise "only if the situation in concern precludes a proper comparison between export price and normal value". ${ }^{110}$ Such observation is in line with WTO jurisprudence. And on the basis of the 2017 EU's report on China, it is difficult to see how PMS will not arise when calculating the margin of dumping. Under Article 2.2 ADA, in order to apply CNV, a causal link between the existence of PMS and the exclusion of proper comparison must be presented.

106 Article VI:1(b)(ii) GATT.

107 AD Agreement Article 2.1.

108 GATT Analytical Index, p.228-229. Available at: https://www.wto.org/english/res_e/booksp_e/gatt_ai_e/art6_e.pdf (accessed in January 2018); Also see: Terence P. Stewart (ed), The GATT Uruguay Round: A Negotiating History (1986-1992) (Volume II), Kluwer Law and Taxation Publishers, 1993. pp.1404-1406. This Ad Note was agreed in the Review Session of 1954-1955, it is a reflection of the Report of the Working Party on the Accession of Poland, Romania and Hungary, due to their special market situation at that time. The Committee on Anti-Dumping Practices established under the 1979 Agreement on Implementation of Article VI of the General Agreement on Tariffs and Trade records that: "In the case of imports from a developing country, the fact that the export price may be lower than the comparable price for the like product when destined for domestic consumption in the exporting country does not per se justify an investigation or the determination of dumping unless the other factors mentioned in Article 5:1 (currently Article 2.2 ADA) are also present". See: GAT'T Analytical Index, p.229

109 The Appellate Body held that the two conditions, namely, a country which has a complete or substantially complete monopoly of its trade, and where all domestic prices are fixed by the state, must be fulfilled cumulatively in order to make the Note applicable. EC-Fasteners, Appellate Body Report, n.460. 110 Zhou and Percival (2016), p.881. 
4. In EC-Cotton Yarn, a GATT Panel found that PMS was only relevant "insofar as it had the effect of rendering the sales themselves unfit to permit a proper comparison"111. In EU-Biodiesel, the Appellate Body held that the distorted domestic production costs due to Argentine export tax system was not, in itself, a sufficient basis for concluding that those costs needed to be disregarded. ${ }^{112}$ It can be seen that PMS may refers to a wide range of issues that rendered the domestic price artificially low, it is nevertheless insufficient to trigger the application of CNV, unless a causal relationship exist between PMS and the exclusion of a fair comparison between export price and normal value. Significant distortion and the precondition of applying CNV in the EU's new legislation may be categorised as a form of PMS, but the lack of a causal relationship between significant distortion and the exclusion of fair comparison maybe contrary to the current WTO jurisprudence. Furthermore, in the anti-dumping investigations initiated by EU toward China, Article 2(6)(a) of the EU's new legislation seems to be inconsistent with Paragraph 15(a) of Accession Protocol. A case may be made with regard to Paragraph 15(a)(ii) as the only justification for non-strict comparison regarding Chinese products. According to the analysis carried out above, such justification already expired in 2016, and no other alternatives are indicated by the wording of Paragraph (d). Therefore, in the absence of new legislation in the EU, they are obliged to provide strict comparison in anti-dumping investigations towards China.

5. Moreover, Article 2(6)a of the EU's new legislation as such arguably contravenes WTO law. In Article 2(6)(a), CNV is based on the costs of production and sale reflecting undistorted prices or benchmarks. The Commission refers to third country and international prices, costs or benchmarks as alternatives of domestic costs of exporting country, while directly disregarding the cost of production from exporting member. ${ }^{113}$ In contrast, Article 2.2 ADA requires that the CNV shall be built upon a comparable price of the like product when exported to third country, or with the cost of production in exporting member plus a reasonable amount for SG\&A and for profits. It does not seem to be in line with Article 2.2.1.1 ADA which elaborates the calculation of CNV under non-strict comparison. ${ }^{114}$ In addition, Article 2(6)(a) of EU's new legislation does not contain specific method in determining undistorted SG\&A and profit, which may expand the powers of the investigating agency. Accordingly, Article 2.2.2 ADA is disregarded.

6. Furthermore, Article 2(6)(a) of the EU's new legislation "as applied" is arguably not in line

111 EC-Imposition of Anti-Dumping Duties on Imports of Cotton Yarn from Brazil, GATT Panel Report, 42S/17.

112 EU-Biodiesel, Appellate Body Report, para. 6.55.

113 Under Article 2(6)a paragraph a, domestic costs is available, but only to the extent that they are positively established not to be distorted, on the basis of accurate and appropriate evidence. Such provision renders the burden of proof to exporting members' producers, which is also a violation of Article 2.2 ADA.

114 By the same token, EU's new legislation also violates Article VI:1 GATT, which uses the costs of production of the product in the country of origin as an element in constructing $\mathrm{CNV}$, no other alternative is provided. 
with WTO law. Article 2.4 ADA requires that "a fair comparison shall be made between the export price and the normal value" and that any differences which affect price comparability shall be subject to adjustment. The method of constructing CNV under the EU's new legislation without a mandatory adjustment requirement affects the fair comparison stipulated under the ADA. ${ }^{115}$ Moreover, GATT Article VI:2, and ADA Article 9.1 and 9.3 require that members shall levy anti-dumping duty less than the margin of dumping in respect of such product, and lesser duty would be desirable if such lesser duty were adequate to remove the injury to the domestic industry. Under the EU's new legislation, the Commission is most likely to adopt higher CNV in the comparison with export prices. Under such circumstance, the margin of dumping may be easily inflated, and the obligation underlined by Article GATT VI:2, and ADA Article 9.1 and 9.3 may be derogated.

\section{CONCLUSION}

1. Paragraph 15 of the Accession Protocol might have expired in December 2016, but the substantive content of the concept of NME in the calculation of dumping margin in the EU has not disappeared. The concept of 'significant distortions' due to state interference, introduced in the new EU's country-neutral legislation still allows the EU investigating authorities to calculate normal value away from using domestic prices of the export country. Accordingly, such calculation may include cost of production and sale in an appropriate third country that is at a similar level of development as the country under investigation. There are a number of issues with this new EU's legislation and how it may apply to imports from China.

2. Firstly, 'significant distortions' is defined as an economy that "prices or costs, including the costs of raw materials and energy, are not the result of free market forces because they are affected by substantial government intervention". ${ }^{116}$ Although the 2017 EU's report assessing the nature of the economy of China, finds that "China has moved from a system where essentially all prices are set by the State" to a more complex system, prices of pharmaceuticals, "fuel, electric power, and other utilities" are still fixed by the state. Moreover land allocations and other prices are distorted as they are

\footnotetext{
115 The adjustment requirement is a controversial issue in WTO jurisprudence. In EU-Footwear, "Fair comparison" was referred to the procedure of comparison, rather than normal value or export price per se. See: European Union-Anti-Dumping Measures on Certain Footwear from China, WT/DS405/R, para.7.265. However, in US-Hot-Rolled Steel, the Appellate Body found that CNV and export price shall be adjusted to ensure a fair comparison. See: Appellate Body Report, United States-Anti-Dumping Measures on Certain Hot-Rolled Steel Products from Japan, WT/DS184/AB/R, para.177. While in the compliance proceeding of EC-Fasteners, both the Panel found that the adjustments in costs may not be required. See: Panel Report, EC-Fasteners (Recourse to Article 21.5 of the DSU by China), para.7.245. However, the EC-Fasteners Compliance case is specifically targeting the situation where the analogue country methodology is used under the NME assumption, the application of the ruling should be regarded as limited.

116 See Section 2.2.2 of the report.
} 
117 See the World Bank's Data on the list of 47 least developed countries. Available at https://data.worldbank.org/?locations=XL-NP (visited March 2018).

118 The term developing country is really an imprecise term based on political, economic and social foundation as well as how other countries perceive a country.

119 European Commission Document SWD(2017) 483 final/2, (20 December 2017).

120 See GATT document MTN.GNG/NG8/W/26/Rev.1 (25 May 1988), the following definition has been given to "input dumping" "... a situation where materials or components used in manufacturing and exported product are purchased internationally or domestically at dumped or below cost prices, whether or not the product itself is exported at dumped prices". See Submission of Japan on the Amendments to the Anti-dumping Code, MTN.GNG/NG8/W/48/Add.1 (29 January 1990), para. VI. 
will be interpreted by the WTO adjudicatory body. Irrespective of the fact that the notion of input dumping has not been historically linked to state intervention, the notion of 'significant distortion' in the new EU's legislation cannot be decoupled from the activities/intervention by a state. This means that in as much as the EU continue to view China's economy as not operating free from state intervention, it would be difficult for the issue of third country cost in the calculation of dumping margin to ebb away. Going forward, WTO members will have to re-think broadly the issue of dumping/anti-dumping as currently regulated by the multilateral trading system. More precisely, the issue of PMS, input dumping as well as the notion of 'significant distortions' raised in the new EU's legislation will need proper discussion by the negotiating arm of the WTO. It is the entire WTO membership that ought to have the last say and clarify the antidumping rules so as to first, ensure a level-playing field in the system and secondly, ensure that some WTO members are not targeted for engaging in legitimate trade practices. 


\title{
China's Market Economy Dilemma and its Interplay with EU Anti-Dumping Law
}

\begin{abstract}
In recent years, the issue of market economy in relation to the status of China as a WTO member has been at the top of heated international debates especially with regard to the expiry of Paragraph 15(d) of the Protocol on the Accession of the People's Republic of China to the WTO (hereinafter "Accession Protocol"). Many commentators had hoped that December 2016 would signal the end of the contestations as to whether China is a market or non-market economy. At the end of 2017, the EU enacted a new anti-dumping and anti-subsidy legislation aimed at addressing state-induced market distortion that will undoubtedly reinvigorate the debates on market and non-market economies at the WTO. The EU practice and the new legislation are yet to be subjected to extensive academic scrutiny. Although the US has also been at the forefront of invoking particular market situation ("PMS") in relation to dumping investigation against imports from China, this paper focuses on China- EU relations vis-à-vis WTO anti-dumping law. It argues that although paragraph 15(d) of the Accession Protocol might have expired in December 2016, the substantive content of the concept of NME in the calculation of dumping margin in the EU has not disappeared. The concept of 'significant distortions' due to state interference, introduced in the 2017 EU's country-neutral legislation, still allows the EU investigating authorities to calculate normal value in a manner that disregards domestic prices of the exporting country. The paper concludes with some remarks on how going forward this contestation can be settled.
\end{abstract}

\section{Introduction}

1. On 10th July 2017, a WTO panel was composed to hear the dispute between China and the EU regarding some of the EU's regulations on the calculation of dumping margin against Chinese imports. ${ }^{1}$ This was after a consultation requested on the 12th of December, 2016 by China had failed to resolve the dispute. ${ }^{2}$ More specifically, China complained that certain provisions of EU and US laws pertaining to classification of China as a 'non-market economy' ("NME"), for the purpose of the determination of dumping margins, were inconsistent with the obligations of the respondents under the GATT/WTO rules. ${ }^{3}$ The request for the establishment

\footnotetext{
1 Accordingly, the panel was established by the Dispute Settlement Body on 03 April 2017 and composed by the WTO DG pursuance to DSU Article 8.7 on the 10 of July 2017. See

WT/DS516/10. On the basis of the communication from the panel hearing the case, the panel report will not be issued before July 2018. See WT/DS516/11 (11 December 2017).

2 DS516, European Union-Measures Related to Price Comparison Methodologies. As of the $4^{\text {th }}$ of September 2017, consultation was still ongoing between China and the US regarding similar measures by the US. See DS515: United States- Measures Related to Price Comparison Methodologies.

3 When China acceded to the WTO in 2001, it was classified as a non-market economy. This allowed
} 
of the panel came after the parties had failed to reach an agreement to reclassify China as a market economy in the WTO. ${ }^{4}$ The EU, US and other WTO members had prior to 2001, classified a number of socialist countries including China as a NME. In the case of China this status, which permits WTO members under certain conditions to use prices in third country markets when investigating antidumping, had been understood to last for a maximum of fifteen years from the date of China's accession to the WTO. ${ }^{5}$

2. At issue in the EC-Measures Related to Price Comparison Methodologies and the US-Measures Related to Price Comparison Methodologies cases is the methodology employed by the EU and the US in the calculation of dumping margin which continued to regard China as a NME. ${ }^{6}$ It is obviously tempting to think that the ruling of the WTO Dispute Settlement Body, whichever way it will go in this case, would settle the issue of whether China is a market or a non-market economy. While the ruling will provide some clarity as to the subject, finally resolving the issue may still need the EU, the US and China to come up with some imaginative approach to implement the report and clarify some of the issues relating to the notion of market and non-market economy in WTO antidumping law. ${ }^{7}$

3. This article starts by analysing the origin of China's market economy status dilemma and EU's approach in classifying China as a NME country. It further examines Paragraph15 of the Accession Protocol of China, as well as certain WTO jurisprudence in relevant cases, in order to shed some lights on how the issue of China market economy status may be resolved going forward. The paper further argues that although paragraph 15 of the Accession Protocol might have expired in December 2016, the substantive content of the concept of NME in the calculation of dumping margin in the EU has not disappeared. The concept of 'significant distortions' due to state interference, introduced in the 2017 EU's country-neutral legislation, still allows the EU investigating authorities to calculate normal value away from using domestic prices

other WTO Members to be able to essentially ignore domestic prices in China when determining whether dumping has occurred by comparing the export price with the domestic price of a third party market. However, Paragraph 15 of China's Protocol of Accession opened the possibility of this status lapsing fifteen years later. On the basis of this, the EU and the US should have started considering China as a market economy as from December 2016.

${ }^{4}$ Paragraph 15 (d) of the Accession Protocol of China in relevant parts states “... [th]e provisions of subparagraph (a)(ii) shall expire 15 years after the date of accession. In addition, should China establish, pursuant to the national law of the importing WTO Member, that market economy conditions prevail in a particular industry or sector, the non-market economy provisions of subparagraph (a) shall no longer apply to that industry or sector." See Accession of the People Republic of China, Decision of 10 November 2001, WT/L/432, (23 November 2001).

${ }^{5}$ See Jean-François Bellis's presentation at the Workshop on "Market Economy Status for China after 2016?" organised by the European Parliament, Brussels, (28 January, 2016), Katarzyna Kaszubska, Rethinking China's Non-Market Economy Status Beyond 2016, ORF Occasional Paper No.107 (JANUARY 2017).

6 WT/DS515/1; WT/DS516/1.

7 Dispute Settlement Understanding (DSU) Article 3.7 encourages WTO members to seek mutually acceptable solution to disputes. 
of the export country.

\section{China's Market Economy Status dilemma-Where does it come from?}

1. When China joined the WTO in 2001, special provisions in determining price comparability in anti-dumping investigations were adopted. Paragraph 15(a) and (d) of the Accession Protocol allows the WTO members to apply special NME methodologies when they investigate import from China in their antidumping laws.

2. However, it is important to note that although the multilateral trading system is based on market economy principles, there is no provision in the WTO defining what a market or a NME is. Neither Article VI of GATT 1994 nor WTO Agreement on Antidumping contain any definition or distinction between a market economy and a NME. These two terminologies are only grounded in the municipal laws of a few WTO members. ${ }^{8}$

3. The NME problem can be traced back to the cold war period, when western countries initiated special trade treatment towards communist/socialist countries. Such treatment was mainly due to state monopoly in all sectors of the economy in such countries. ${ }^{9}$ It became prominent in the multilateral trading system, during the negotiations of the failed International Trade Organization ("ITO"), in anticipation of Russia's membership. ${ }^{10}$ As the ITO was never realized, the issue of state trading enterprises or NME was initially abandoned and was only brought back into the multilateral forum in 1955, during the GATT Review Session. ${ }^{11}$ As a consequence, $A d$ Note to Article VI:1 was added to GATT 1947 and then, carried forward to GATT 1994. The Ad Note reads; "[i]t is recognized that, in the case of imports from a country which has a complete or substantially complete monopoly of its trade, and all domestic price are fixed by the state"12, a strict comparison with domestic prices in such a country may not always

\footnotetext{
${ }^{8}$ For an analysis on some WTO member's law on the concept of Market and NME, see Laura Puccio, Granting Market Economy Status to China: An analysis of WTO law and of selected WTO members' policy, European Parliament Research Service, PE 571.325, (November 2015). Available at http://www.europarl.europa.eu/RegData/etudes/IDAN/2015/571325/EPRS_IDA(2015)571325_E N.pdf (accessed, September 2017).

9 Robert Crawford, Regime Theory in the Post-Cold War World: Rethinking Neoliberal Approaches to International Relations, Dartmouth Publishing, 1996. p.53.

10 Russia never became a member though.

11 See Robert E. Hudec, Developing Countries in the GATT Legal System, (CUP, 1987), A comprehensive analysis of this case is given in Robert E. Hudec, The GATT Legal System and World Trade Diplomacy (Butterworth Legal Publisher, 1990), Mary E. Footer, An Institutional And Normative Analysis of the World Trade Organization, (Martinus Nijhoff Publishers, 2006).

12 See Ad Note 1(2) to Article VI of GATT 1994.
} 
be appropriate, therefore, flexibility is allowed in terms of normal price determination. Accordingly, certain WTO members, notably the US and EU developed special treatment in targeting those countries, i.e. third country methodology and single rate method. The special treatment is also codified in WTO accession protocols of several formal socialist countries including that of China. ${ }^{13}$ Therefore, consistent with the provision, WTO members may deviate from the requirement of Article 2.1 of the Agreement on antidumping when calculating the margin of dumping in the case of centrally planned economies ("CPE") ${ }^{14}$ by using third country price or analogue country methodology.

\section{II.1 The Concept of NME in the EU municipal Law}

1. As indicated above, the concept of NME is not per se, a legal terminology in GATT/WTO law. It is a terminology that has only been codified in some WTO Members' legislations and policies. The United States for instance, defines non-market economy as "any foreign country that does not operate on market principles of cost or pricing structures, leading to sales that do not reflect a product's fair value." 15 Although China has for a long time been treated as a NME in EU antidumping practice, NME does not have a concrete definition within EU law. Relevant EU legislations only contain a somewhat non-exhaustive list of countries that are regarded as NME. ${ }^{16}$ This list contained some former Eastern European countries that have long graduated and are also currently EU member states. ${ }^{17}$ In this regard, the EU has enacted many regulations relating to state trading enterprises. However, it was only in 2008 , following numerous requests by China to be classified as a market economy that the Commission came up with five criteria that China would have to fulfil in order to be reclassified as a market economy. ${ }^{18}$ To summarise, NME is an economy where "prices and costs are artificially low and hence do not reflect normal market

\footnotetext{
13 See also US-Vietnam WTO-Coalition on Vietnam's designation as a NME by the US, USTR, http://www.usvtc.org/trade/wto/coalition/WTOCoalition-FactsheetNME27Jul06.pdf (accessed September 2017).

14 The concept of CPE was used until early 1990s to refer to countries where economic activities "were based on yearly plans usually elaborated by a body like state planning commission". These countries were mostly Central and Eastern European, USSR, China, Vietnam etc. See Walter Goode, Dictionary of Trade Policy Terms, $4^{\text {th }}$ ed, (CUP, 2003), p. 57.

15 See Evaluation of China's Non-market Economy Status, US-China Economic and Security Commission, Issue Brief, (18 April, 2017), citing Tariff Act of 1930, Pub. L. No. 103-465, 1930, Codified at 19 U.S.C, $\$ 1677(18)$.

16 Council Regulation (EC) No 1225/2009 of 30 November 2009 on protection against dumped imports from countries not members of the European Community.

17 The first regulations dealing with issue of NME was Regulation 109/70 of 19 December 1969 establishing common rules for imports from state-trading countries (covering Bulgaria, Hungary, Poland, Romania, Czechoslovakia and USSR). China was included in the amended Regulation in 1978. 18 See Commission Staff Working Document on progress by the People's Republic of China towards graduation to market economy status in trade defence investigations, 19/09/2008, SEC (2008) 2503 final, p. 6. A revision on these criteria in 2011 found that only one of the five criteria was met by China, i.e., no state intervention in companies linked to privatization. See European Parliament, Policy Briefing, Trade and Economic Relations with China in 2013, p. 24.
} 
forces. Therefore, for non-market economies, domestic prices are not used as a benchmark against which to compare export prices". ${ }^{19}$

2. As can be seen from the foregoing, the determination as to whether a particular WTO member is a NME or not seems to hinge on how the EU legislation or policy on NME or state trading enterprises is drafted. While the manner in which Paragraph 15 (d) of the Accession Protocol is interpreted is key in the determination of China's NME/market economy status, EU practice seems to provide essentially, an unquestionable flexibility to the Commission to impose duties on Chinese imports. Recently, in a DSU Article 21.5 compliance panel, the Appellate Body upheld most of the panel findings relating to a dispute brought by China regarding EU approach to the calculation of dumping margin against Chinese iron and steel products. ${ }^{20}$ And by the end of 2013, 62\% of all EU anti-dumping measures were against China. ${ }^{21}$ Weijia in a 2013 article shows how the negative effects of anti-dumping measures extend beyond the obvious loss of revenue.22 That loss in revenue resulted in a fall in $\mathrm{R} \& \mathrm{D}$ for instance, having productivity implications for the NME. Overall, as a consequence of China's status as a NME, China was subject to $19.4 \%$ of the world's anti-dumping investigations between 1995 and 2008.23

3. For instance, in the dispute concerning Colour Television Receivers from China, identical TVs were exported to the US market by companies in Malaysia and China. The Chinese TVs had 78\% of duties imposed, the Malaysians none. As a NME, the US ascertained the normal value of the Chinese product by using India as a surrogate. ${ }^{24}$ Discriminatory terms were seen as necessary "in order [for established WTO members] not to be challenged by transition economy newcomers under the WTO system." 25 The idea that China is different remains today and it "is being used to justify limitless discretion" when it comes to antidumping and countervailing measures. ${ }^{26}$ In other words, the benchmark in determining "market economy status" is only subject to the discretion of the individual WTO members.

19 European Commission - Fact Sheet, Brussels, (13 January 2016), available at http://europa.eu/rapid/press-release MEMO-16-61 en.htm (accessed, September 2017).

20 Appellate Body Report, European Communities - Definitive Anti-Dumping Measures on Certain Iron or Steel Fasteners from China, WT/DS397/AB/R, (adopted, 12 February, 2016).

${ }^{21}$ Commission Staff Working document: $33^{\text {rd }}$ Annual Report from the Commission to the Council and the European Parliament on the EU's Anti-Dumping, Anti-Subsidy and Safeguard Activities SWD(2015) 149, final, Brussels.

22 Weijia Rao, China's Market Economy Status Under WTO Antidumping Laws After 2016, Tsinghua China Law Review, Vol. 5, (2013).

${ }^{23}$ See Rui Pan, China's WTO Membership and the Non-Market Economy Status: discrimination and impediment to China's foreign trade, Journal of Contemporary China, Vol. 24, No. 94 (2015), p. 748

${ }_{24}$ See Weijia Rao, China’s Market Economy Status Under W'TO Antidumping Laws After 2016, Tsinghua China Law Review, Vol. 5, (2013), P. 154.

25 Page 3 Poletkov

${ }^{26}$ K. William Watson, Will Non-market Economy Methodology Go Quietly into the Night? U.S. Antidumping Policy toward China after 2016, Cato Institute Publication No 763, (October, 2014), p. 3 
4. The evolution of regulations adopted by the $\mathrm{EU}^{27}$ shows that the EU legislative body reframed the NME lists constantly. The EU granted full market economy status to Russia and Ukraine in $2002^{28}$ and $2005^{29}$ respectively, while alternative calculation method, i.e. cost adjustment method, was built in the normal value provision, which lead to contentious disputes from then on. As to China's position in EU anti-dumping regulation, a conditional market economy status has been granted to individual producers upon their voluntary application in 1998 (the MET application). Such method remained active until the new regulation ${ }^{30}$ was enacted in 2017.31

5. In DS405, China asserted that at the time of the original investigation, the Commission only examined the MET applications of companies selected for the sample of Chinese exporting producers, and never examined the MET applications submitted by non-sampled cooperating Chinese exporting producers. The non-sampled companies had no chance of receiving any disclosure regarding the results of their MET applications. ${ }^{32}$ The Panel found in favour of the EU and stated that Article 2.4 of the ADA does not establish any requirements with respect to either sampling, or the establishment of normal value. China failed to demonstrate how Article 2.4 regulates MET applications or the use of sampling in examining MET applications. ${ }^{33}$ The same reasoning has also been used in Panel's determination of whether Paragraph 15(a)(ii) constitutes a legal basis in challenging EU's practice. ${ }^{34}$ The Panel stated that, in order to challenge EU's practice, China needs to demonstrate that sampling is prohibited for purposes of

\footnotetext{
2720 countries were listed as State-Trading Countries under the EU's previous regulation (Council Regulation (EC) No 519/94, OJ L 67, 10.3.1994). The State-Trading Country list was renamed as Non-Market Economy Country list in 1996 (Council Regulation (EC) No 384/96, OJ L 56, 6.3.1996). Several countries have been taken off from the list either based on accession in the EU (i.e. Estonia, Latvia, Lithuania) or specific recognition (Russia and Ukraine). See: Council Regulation (EC) No 905/98, OJ L 128, 30.4.1998; Council Regulation (EC) No 1972/2002, OJ L 305, 7.11.2002; Council Regulation (EC) No 2117/2005, OJ L 340, 23.12.2005.

28 Ibid, Council Regulation (EC) No 1972/2002, OJ L 305, 7.11.2002

29 supra note 27, Council Regulation (EC) No 2117/2005, OJ L 340, 23.12.2005

30 See The EU's new trade defence rules and first country report, European Commission - Fact Sheet, (20 December 2017). Available at http://europa.eu/rapid/press-release_MEMO-17-5377_en.htm

31 while based on the regulation 1225/2009, China was not listed in the conditional market economy treatment list. It seems that China had graduated from the NME list, similar to what the EU did in the cases of Russia and Ukraine. However, the Corrigendum re-listed China and Vietnam in 2010, imposed the conditional treatment to Chinese producers.

32 WT/DS405/R, Panel Report. China asserts independent violations of Article 2.4, 6.10.2, and 17.6(i) of the ADA, Paragraph 15(a)(ii) of China's Accession Protocol, and Paragraphs 151(e) and (f) of China's Working Party Report. China asserted that the EU practice was in violation of paragraph 15(a)(ii) of AP and Paragraphs 151(e) and (f) of the Working Party Report, which requires importing WTO Members to "provide Chinese producers and exporters a full opportunity for the defense of their interests in a particular case." See: para. 7.168.

33 Ibid, para.7.189.

34 Ibid, para.7.197.
} 
making the MET determination, and the criteria on which the sample was selected were unjustified. ${ }^{35}$ DS405 reaffirmed EU's discretion in determining MET criteria, as well as in selecting the surrogate country.

\section{II.2 Interpreting Paragraph 15 of Accession Protocol}

1. For the purpose of understanding how going forward the status of China in the WTO may be viewed, we briefly look at the Paragraph that until December 2016 underlined China's status as a NME. The relevant parts of Paragraph 15 are therefore reproduced below.

Subparagraph (a)(ii) of this Paragraph reads:

"[t]he importing WTO Member may use a methodology that is not based on a strict comparison with domestic prices or costs in China if the producers under investigation cannot clearly show that market economy conditions prevail in the industry producing the like product with regard to manufacture, production and sale of that product". Subparagraph (d) provides for conditions under which subparagraph (a)(ii) becomes inapplicable. The subparagraph in its entirety reads:

"Once China has established, under the national law of the importing WTO Member, that it is a market economy, the provisions of subparagraph (a) shall be terminated provided that the importing Member's national law contains market economy criteria as of the date of accession. In any event, the provisions of subparagraph (a)(ii) shall expire 15 years after the date of accession". In addition, should China establish, pursuant to the national law of the importing WTO Member, that market economy conditions prevail in a particular industry or sector, the non-market economy provisions of subparagraph (a) shall no longer apply to that industry or sector."

2. The chapeau of Paragraph $15(a)^{36}$ read together with subparagraph (a)(ii) permits the investigating authority of an importing WTO member to ignore domestic prices or cost in China and to use a methodology that is based on price comparison in a surrogate market or third party market. However, to the extent that producers under investigation can demonstrate that market economy conditions exist in the domestic industry producing like products, the third party or surrogate market methodology will not be applied. In other words, the NME methodology will not be used. This subparagraph has essentially been the core of China's non-market economy status since China acceded to the WTO in 2001.

3. Paragraph 15(d) on the other hand, contains an expiration clause to Paragraph 15(a)(ii) after fifteen years of China's membership to the WTO. In this regard, the subparagraph suggests that

35 Ibid para.7.201.

36 The chapeau reads; "Article VI of the GATT 1994, the Agreement on Implementation of Article VI of the General Agreement on Tariffs and Trade 1994 ("Anti-Dumping Agreement") and the SCM Agreement shall apply in proceedings involving imports of Chinese origin into a WTO Member consistent with the following:...." 
China should no longer be classified as a NME as from 12th December, 2016.37 While China continues to insist that it had graduated from its NME status to a market economy as of 12th December, 2016; there have been conflicting interpretations of this subparagraph. One interpretation of Paragraph 15(d) holds that the expiration of subparagraph 15(a)(ii) only means that NME may not apply in all cases. In other words, market economy shall apply to the extent that a Chinese exporter can demonstrate that it conforms to the criteria for market economy within the internal laws of the importing country. Such internal law containing criteria for NME should have existed by the $11^{\text {th }}$ of December, 2001 when China joined the WTO.38 The second view interprets the provision as meaning that the burden of proving the existence of NME with regard to a particular Chinese exporter will be on domestic producer in the importing country. ${ }^{39}$ In this regard, the burden of proof is on a particular EU importer in question. Similarly, some other interpretations firmly concur with the view that subparagraph 15(a)(ii) automatically expired on 12th December, 2016.40 This latter approach seems plausible if one is to go by the following sentence under subparagraph 15(d) that states "In any event, the provisions of subparagraph (a) (ii) shall expire 15 years after the date of accession". This means that in no other circumstances post December 2016 would subparagraph 15(a)(ii) or second Ad Note 2 to GATT Article VI.1 apply with regards to anti-dumping investigation concerning Chinese imports into the EU.

4. 11 out of 15 disputes brought by China before the WTO DSB have targeted trade remedy laws in the US and EU, among which, four cases ${ }^{41}$ cited Paragraph 15 of the Accession Protocol, and

$37 \mathrm{WT} / \mathrm{L} / 432$ at p. 9.

38 European Parliament, Workshop: Market Economy Status for China after 2016? (2016), available at: http://www.europarl.europa.eu/RegData/etudes/STUD/2016/535023/EXPO_STU(2016)535023

EN.pdf (accessed on 1 May 2017); Joris Cornelis, 'China's Quest for Market Economy Status and its Impact on the Use of Trade Remedies by the European Communities and the United States' Global Trade and Customs Journal, Vol. 2, Issue 2, (2007), pp. 105-115; Barbara Barone, One year to go: The debate over China's market economy status (MES) heats up, Directorate-General for External Policy, European Parliament document: DG EXPO/B/PolDep/Note/2015_330 (2015), pp. 12-13, available at: http://www.europarl.europa.eu/RegData/etudes/IDAN/2015/570453/EXPO_IDA(2015)570453 EN.pdf (accessed September 2017).

39 See Jorge Miranda, Interpreting Paragraph 15 of China's Protocol of Accession, Global Trade \& Custom Journal, Vol. 9, Issue 3, (2014), pp. 94-103, See also interesting comment on the same by Theodore R. Posner, A Comment on Interpreting Paragraph 15 of China's Protocol of Accession, Global Trade \& Custom Journal, Vol. 9, Issue 4, (2014), pp. 146-153.

40 Weijia Rao, China's Market Economy Status Under WTO Antidumping Laws After 2016, Tsinghua China Law Review, Vol. 5, (2013), pp. 151-168, Matthew R. Nicely, Time to Eliminate Outdated Non-Market Economy Methodologies, Global Trade \& Customs Journal Vol. 9, Issue 4, (2014), pp. 160 164; Bernard O'Connor, Much Ado About 'Notbing': 2016, China and Market Economy Status, 10(5)

Global Trade \& Customs Journal, Vol. 10, Issue 5, (2015), pp. 176-180.

41 Against EU: DS397 and DS405; against the US: DS379 and DS 437. 
two of them were brought up before the DSB based on Paragraph 15(d).42 It is worth to explore to what extent subparagraph (a)(ii) is distinct from general WTO law, and whether the expiry of such subparagraph completely brings this distinction to an end.

5. With regards to the issue of the place of subparagraph (a)(ii) within the WTO law, it is worth revisiting the general WTO legal architecture in terms of determining normal value of products as stipulated in GATT Article VI:1 and ADA Article 2. As discussed above, both of these provisions state that normal value is a "comparable price, in the ordinary course of trade". ${ }^{43}$ In defining "comparable prices", Article 2.2 ADA enumerates three other acceptable scenarios where no proper comparison is available. ${ }^{44}$ Article $2.3 \mathrm{ADA}$, the first and second Ad Notes to Article VI:1 go one step further in explaining the more detailed situation where comparable price shall be determined other than domestic prices. Article 2.3 recognises that export price may need to be "constructed on the basis of the price at which the imported products are first resold to an independent buyer" when "export price is unreliable because of association or compensatory arrangement between exporter and importer or a third party", which emphasizes the importance of independence between buyer and seller. ${ }^{45}$ In this regard, the Second Ad Note to GATT Article VI:1 recognises that, "in the case of imports from a country which has a complete or substantially complete monopoly of its trade and where all domestic prices are fixed by the State,... importing contracting parties may find it necessary to take into account the possibility that a strict comparison with domestic prices in such a country may not always be appropriate." It is hence indicated that comparable prices "in the ordinary course of trade" shall be market-determined, reflecting arm's-length transactions between buyer and sellers. ${ }^{46}$ Investigating authorities of contracting parties therefore, have the obligation to prove that their decisions of not using domestic price are well grounded under the previous provisions, otherwise, domestic price shall be deemed as "comparable", and that no other proxy is available or subject to the determination of dumping comparison.

6. As indicated above, Paragraph 15(a) of Accession Protocol is comprised of its chapeau and subparagraphs (a) (i) and (a) (ii). The chapeau of Paragraph 15(a) indicates that there are two options for investigating authorities in determining price comparability under GATT Article VI

42 DS515 and DS516.

43 GATT VI:1 and Article 2.2 ADA. (cite different expressions)

44 ADA Article 2.2 says: "When there are no sales of the like product in the ordinary course of trade in the domestic market of the exporting country or when, because of the particular market situation or the low volume of the sales in the domestic market of the exporting country,..."

45 First Note Ad Article VI:1 also states that "the sale by an importer at a price below that corresponding to the price invoiced by an exporter with whom the importer is associated..., the margin of dumping may be calculated on the basis of the price at which the goods are resold by the importer."

46 Appellate Body Report in US-Hot Rolled Steel, para.142, AB states that a price for a sale may not reflect the criteria of the marketplace, such as profit-maximization. 
and ADA. In terms of whether domestic prices of China should be used to calculate a normal value for comparison or not, the chapeau per se, is an introductory provision which may not be deemed as creating a separate obligation on a WTO member. ${ }^{47}$ The two options are respectively reflected under subparagraphs (a)(i) and (a)(ii).

7. Pursuant to subparagraph (a)(i), importing WTO members shall use Chinese prices or costs to determine price comparability; provided that Chinese producers under investigation can clearly show market economy conditions prevail in the 'like product' industry. Once Chinese producers fail to prove the above criteria, non-Chinese prices or costs shall be available for importing members according to subparagraph (a)(ii). The two subparagraphs clearly allocate the burden of proof on Chinese producers in every investigation that is initiated by importing members. The above options are the only two choices that are available to importing members. Yet, their scope of application does not overlap with each other. ${ }^{48}$ Once subparagraph (a)(ii) expires, the second option, namely, to use non-Chinese prices and costs in price comparison, shall no longer be available for any importing member. Therefore, according to Paragraph 15(d), 12th December, 2016 shall be the termination date for the second option. In other words, going forward, non-Chinese prices and costs shall not be a choice for the determination of normal value.

8. Some commentators argue that, even if subparagraph (a)(ii) expired, China would still have to meet the criteria set forth by the individual importing member in order to qualify for a market economy status. ${ }^{49}$ The foregoing view tends to stress the wording of the chapeau and subparagraph (a)(i), contending that the ongoing effectiveness of the other parts of paragraph 15 is sufficient for the continued labelling of China as a NME. The burden of proof, according to this view of a market economy condition, would continue to rest on Chinese exporters. ${ }^{50}$

9. Central to the arguments against China's market economy status post 2016, is the fact that

47 The structure of Paragraph 15 indicates that there is no independent right conferred by the Chapeau, hence, it cannot be operated independently. It is different from the chapeau of Article 2.2.2 of the ADA and Article XX of the GATT 1994, as both of them entail specific obligations that Members have to comply with. See: Minyou Yu, and Jian Guan, "The Non-Market Economy Methodology Shall be Terminated After 2016", (2017) 12 Global Trade and Customs Journal, Issue 1, pp.16-24.

${ }_{48} I d$. Weihuan Zhou (2017), The author describes the two subparagraphs as "two sides of one coin".

49 Terence Stewart et al, "The Special Case of China: Why the Use of a Special Methodology

Remains Applicable to China After 2016”, (2014) 9 Global Trade and Customs Journal, Issue6, pp.272-279; Jorge Miranda, "More on Why Granting China Market Economy Status after December 2016 is Contingent upon Whether China Has in Fact Transitioned into a Market Economy" (2016) 11 Global Trade and Customs Journal, Issue 5, pp.244-250; Paul C. Rosenthal, Jeffrey S. Beckington, "The People's Republic of China: A market Economy or Non-Market Economy in Anti-Dumping Proceedings Starting on December 12, 2016?” (2014) 9 Global Trade and Customs Journal, Issue 7/8, pp.352-355.

50 Jorge Miranda, 'Implementation of the 'Shift in Burden of Proof' Approach to Interpreting Paragraph 15 of China's Protocol of Accession" (2016) 11 Global Trade and Customs Journal, Issue 10, pp.447-453. 
subparagraph (a)(ii), which should have expired in 2016 is not the one that gives members the right to treat China as a NME; it rather allows members, recourse to NME methodology by default. ${ }^{51}$ Accordingly, members' right to rely on NME assumption is embedded in chapeau of subparagraph (a) (i) as well as subparagraph (d). The wording of the second sentence of paragraph 15(d) provides for the expiry of subparagraph 15(a)(ii) instead of Paragraph 15(a) as a whole. Hence, the expiration did not affect members' right to apply NME assumption, it just terminates members' right to use surrogate price when "producers under investigation cannot clearly show that market economy conditions prevail...". As long as China's whole economy, or individual industry or sector remains NME, according to importing member's domestic criteria in determining market economy status; NME assumption is still in the hands of importing members. ${ }^{52}$

10. Treaties usually represent compromise between contracting parties. The WTO Treaty system is no different. Therefore, just like any other treaty, the Accession Protocol and in particular, Paragraph 15 raises some interpretative issues. Interpreting Paragraph 15 in light of the Vienna Convention ("VCLT") 53 , the above arguments that advocate for continuous application of NME status on Chinese products seems incongruous with the spirits of Paragraph 15(d) for the following reasons:

10.1. First, according to VCLT Article 31(1), the following must be at the centre of treaty interpretation, namely; 'ordinary meaning of terms', 'good faith' 'context' and 'object and purpose'. Consistent with the 'terms' of the treaty at hand, subparagraph (d) is comprised of three independent sentences. The first and third sentence stipulate that subparagraph (a) shall be terminated as a whole provided that China or particular industry/sector of China fulfils the criteria of market economy under the importing members' national law. The second sentence

\footnotetext{
51 Jorge Miranda, "A comment on Vermulst's Article on China in Anti-dumping Proceedings After December 2016" 11 Global Trade and Customs Journal Issue 7/8, pp.306-313.

52 In supporting such argument, paragraph 150 of the Working Party Report is frequently quoted by scholars. They contend that such paragraph denotes China was in a process of transition towards a market economy, and such transition justified other importing members to use NME method in the calculation of normal value. Importing members' domestic law sets forth the criteria in recognizing China's transition. As subparagraph (d) did not set the cut-off date to recognize China as a market economy for importing members, the justification of NME Assumption remains intact after 2016. See: Jorge Miranda, Implementation of the 'Shift in Burden of Proof' Approach to Interpreting Paragraph 15 of China's Protocol of Accession", supra note. 77.

53 Rules for Treaty Interpretation from the Vienna Convention on the Law of Treaties, signed at Vienna, 23 May 1969: UN Doc A/Conf39/28. Vienna Convention was endorsed by WTO tribunals in interpreting WTO agreements. The Appellate Body has acknowledged that the interpretative methodology set out in Article 31 and 32 of the Vienna Convention "has attained the status of a rule of customary of general international law", WTO tribunals are mandated to adhere when interpreting the covered agreements. See: Appellate Body Report, United States—Standards for Reformulated and Conventional Gasoline, WT/DS2/AB/R, 20 May 1996, p.17.
} 
states that subparagraph (a)(ii) shall expire after 15 years 'in any event'. ${ }^{54}$ According to Oxford English dictionary, "in any event" means "for anything that might happen". ${ }^{55}$ This means that for anything that might happen subparagraph (a)(ii) should have expired in December 2016. As analysed above, the chapeau and subparagraph (a)(i) do not contain any words that convey right to the importing members to use non-Chinese prices or cost. The expiration of subparagraph (a) (ii) means that the application of non-Chinese prices or cost is no longer possible on the basis of paragraph 15. The contention that the expiration of subparagraph (a)(ii) means that importing members shall no longer apply non-Chinese prices and cost automatically, but it does not terminate the right of application; seems inconsistent with the original text. The primacy of the text in interpretation is well recognised by international tribunals and is now uncontested in WTO jurisprudential progressivism. ${ }^{56}$ It is widely recognised that interpretation must be firmly rooted in the text of the treaty in question. ${ }^{57}$ In this regard, had negotiators intended to continue the application of non-Chinese prices and costs, they could have perhaps specified unequivocally so, in the chapeau or subparagraph (a)(i). It may therefore be submitted that to the extent that a particular right or obligation does not form an express part of a treaty, an interpreter would be estopped from reading the treaty in a way that may add or subtract such right or obligation. ${ }^{58}$

10.2. Second, international tribunals tend to stress the fundamental importance of 'good faith'59 in treaty interpretation. ${ }^{60}$ Good faith applies to the whole process of interpreting a treaty rather than solely to the meaning of particular words or phrases of the text. ${ }^{61}$ Although subjective in

54 It is one of the strongest terms to mandate certain action without any exception. Such expression leaves no room or possibility for the importing members to manipulate the interpretation of the expiration affect of subparagraph 15(a)(ii).

55 See Oxford English Dictionary, (2018). Available at https://public.oed.com/the-oed-today/recent-updates-to-the-oed/ (Visited on 16 March 2016). 56 As pointed out by the AB in US - Carbon Steel, "...the task of interpreting a treaty provision must begin with its specific terms...”. See AB Report, WT/DS213/AB/R, para. 62, AB Report, EC — Hormones, para. 181, AB Report, US - Softwood Lumber IV, para. 59 etc.

57 International tribunals have usually rejected otherwise reasonable interpretations because to accept them would have been tantamount to rephrasing or otherwise altering the actual text. See: Richard Gardiner, Treaty Interpretation, Second Edition, Oxford University Press, 2009.

58 "Sometimes the absence of something means simply that it is not there". See: Appellate Body Report, Canada_Term of Patent Protection, WT/DS170/AB/R (2000), para.78. Also see: Richard Gardiner (2009), p.165.

59 According to the definition of good faith in Black's Law Dictionary, "'Good faith' performance or enforcement of a contract emphasises faithfulness to an agreed common purpose and consistency with the justified expectations of the other party; it excludes a variety of type of conduct characterized as involving 'bad faith' because they violate community standards of decency, fairness and reasonableness.” Bryan A. Garner, Black’s Law Dictionary, West Group, 701, (1999) (hereinafter, Garner).

60 See: John F. O’Connor, Good Faith in International Law, Dartmouth: Aldershot, 1991.

61 Richard Gardiner (2009), p.168. As was pointed out by the WTO AB in one of its early report "... [P] erformance of treaties is also governed by good faith. Hence, Article 26 of the Vienna Convention, entitled Pacta Sunt Servanda, to which several appellees referred in their submissions (foot note omitted), provides that '[e]very treaty in force is binding upon the parties to it and must be enforced by them in good faith'(foot note omitted). Clearly therefore, there is a basis for a dispute 
explaining the content of good faith, it is commonly related to the principle of effectiveness and reasonableness whose interpretation may be linked to the history and preparatory work, the context, as well as the object and purpose of the treaty. ${ }^{62}$ In addition, good faith requires the balancing of treaty elements when interpreting. ${ }^{63}$

10.3. Moreover, despite the contestation regarding the expiration of China NME status, many commentators have put forward compelling arguments in support of the 2016 expiration deadline based on paragraphs 150 and 151 of the Report of the Working Party on the Accession of China (Working Party Report). ${ }^{64}$ Paragraph 151 clearly expresses that when applying NME methodology, as stipulated under subparagraph 15(a)(ii), a WTO member with municipal law on NME at the time of China accession must follow strict criteria identified under paragraph 151 (a-f). It can be seen that subparagraph (a)(ii) is the only legal ground for NME status. Both paragraph 15 of Accession Protocol and the Working Party Report are supplementary rules to GATT Article VI and the ADA, when it comes to price comparison during China's transition period. Moreover, paragraph 151 further demonstrates the common intentions of the parties which must 'add colour, texture and shading'65 to any interpretation of paragraph 15 of the Accession Protocol. ${ }^{66}$ Thus, paragraph 15 is a time-bound provision whose operation terminated in 2016. In view of the well-known principle of effectiveness in treaty interpretation, to the extent that the EU and the US continue to use the surrogate country post-2016 in the determination of market price for the purpose of calculating of dumping margin, the effectiveness of the second sentence of subparagraph 15(d) will be undermined. As was reiterated by Lauterpacht in his seminal article titled 'Restrictive Interpretation and the Principle of

settlement panel to determine, in an appropriate case whether a Member has not acted in good faith" See Appellate Body Report, United States - Continued Dumping and Subsidy Offset Act of 2000, adopted January 27, 2003, WT/DS217/AB/R, WT/DS234/AB/R, paras. 296 and 297.

62 Richard Gardiner (2009), pp.172-180, see also Thomas Wilhelmson,"Good Faith and the Duty of Disclosure in Commercial Contracting - The Nordic Experience," in Cottier and Schefer, 53 (2000).

${ }^{63}$ Ngangjoh-Hodu, Pacta Sunt Servanda and Complaints in the WTO Dispute Settlement Manchester Journal of International Economic Law (MJIEL)-Vol. 1, Issue 2, 2004, pp. 76-96 as well as Richard Gardiner (2009), p.178.

${ }^{64}$ Report of the Working Party on the Accession of China, Doc WT/ACC/CHN/49 (1 October 2001). Articles analyzing such issue are selected as follows: Zhenghao Li, Interpreting Paragraph 15 of China's Accession Protocol in Light of the Working Party Report, (2016) Global Trade and Customs Journal, 11(5), pp.233-234; Andrei Suse, “'Old Wine in a New Bottle': The EU's Response to the Expiry of Section 15(a)(ii) of China's WTO Protocol of Accession", KU Lewven Working Paper No.186, May 2017; Jochem de Kok, "The future of EU Trade Defence Investigations against Imports from China"(2016) Journal of International Economic Law, pp.525-528; David Kleimann, "The Vulnerability of EU Anti-Dumping Measures against China after December 11, 2016”, EUI Working Papers RSCAS 2016/37, July 2016.

${ }_{65}$ See AB Report in US - Shrimp, WT/DS58/AB/R, para. 153.

${ }^{66}$ As has been demonstrated in WTO jurisprudence, “... The purpose of treaty interpretation is to establish the common intention of the parties to the treaty." See AB Report in EC - Computer Equipment, WT/DS62, 67, 68/AB/R, paras. 84 and 93, AB Report, EC — Cbicken Cuts, para. 93. 
Effectiveness in the Interpretation of Treaties' ${ }^{9}$, the so-called restrictive interpretation of treaties must be avoided by an interpreter. Such interpretation would be incongruous with the object and purpose of paragraph 15.11. Article 15 of the Accession Protocol has been cited in several WTO disputes brought up by China. ${ }^{68}$ As noted earlier, in EC-Fasteners, the WTO Appellate Body interpreted Paragraph 15(d) of the Accession Protocol. It held that:

"Paragraph 15(d) of China's Accession Protocol establishes that the provisions of paragraph 15(a) expire 15 years after the date of China's accession (that is,11 December 2016). It also provides that other WTO Members shall grant before that date the early termination of paragraph 15(a) with respect to China's entire economy or specific sectors or industries if China demonstrates under the law of the importing WTO Member that it is a market economy' or that 'market economy conditions prevail in a particular industry or sector'." 69

11. It can be seen that the Appellate Body's interpretation was in line with the above analysis. The answers to the two questions also become explicit. First, subparagraph (a)(ii) provides legal basis for the importing members to disregard Chinese prices and costs, should Chinese producers fail to prove its market economy status under importing members' domestic law. With regard to the second sentence of paragraph 15(d), the special methodology expired in December 2016 and the importing members may no longer take recourse to subparagraph 15(a)(ii) to justify their application of non-Chinese prices and cost. It is therefore, arguably clear that on the basis of the remaining part of paragraph (a), once China fails to prove market economy criteria under importing members' domestic law, importing members shall only take recourse to general WTO law to find alternative method in calculating normal value.

\section{II.3 Interpretation of NME in the Context of EU law}

1. In terms of the judicial interpretation regarding Art.2(7), the judgment of the ECJ in case European Commission v. Rusal Armenal $\mathrm{ZAO}^{70}$ is worth noting. Rusal Armenal $\mathrm{ZAO}$ is an Armenian manufacturer and exporter of aluminum products Armenia is a WTO member since 2003. In 2008, the European Communities initiated an antidumping proceeding against certain aluminum products originating in Armenia, Brazil and China. ${ }^{71}$ Rusal Armenal Zao first brought the case to the General Court, where the company disputed the classification of Armenia amongst the NME countries pursuant to Art.2(7) of Council Regulation No.384/96 ("The Basic

${ }^{67} \mathrm{H}$. Lauterpacht, Restrictive Interpretation and the Principle of Effectiveness in the Interpretation of Treaties, 26 Brit. Y.B. Int'l L. 48 (1949).

${ }^{6}$ United States-Definitive Anti-dumping and Countervailing Duties on Certain Products from China, DS379;

European Communities-Definitive Anti-Dumping Measures on Certain Iron or Steel Fasteners from China, DS397;

United States-Countervailing Duty Measures on Certain Products from Cbina, DS437.

${ }_{69} \mathrm{WT} / \mathrm{DS} 397 / \mathrm{AB} / \mathrm{R}$, para. 289.

70 European Commission v. Rusal Armenal ZAO, Judgment of ECJ of 16 July 2015,

ECLI:EU:C:2015:494.

71 OJ 2008 C 177, p.13. 
AD Regulation"). ${ }^{72}$ In addition, the company submitted a claim to be granted market economy treatment or individual treatment which falls under Art.2(7)(c) should the previous claim fail. In response, the Commission concluded that Armenia could not be regarded as a market economy, as it was listed in the footnote of Art.2(7)(a) of the Basic AD Regulation, and the company did not satisfy the criteria that is contained within Art.2(7)(c). The general court upheld that Art.2(7) of the Basic AD Regulation was contrary to Art.2.7 of the Anti-Dumping Agreement set out in Annex 1A to the Agreement Establishing the WTO, and hence, such provision was annulled in so far as it concerned Rusal Armenal. ${ }^{73}$

2. The case was appealed by the Commission on three grounds: firstly, the General Court had ruled ultra petita; secondly, the General Court had erred in law in holding that Article 2(7) of the basic regulation is intended to implement the particular obligations assumed in the context of the WTO and; thirdly, there had been an infringement of the general principle of institutional balance. ${ }^{74}$ The ECJ upheld the second ground of appeal, and pointed out that given their nature and purpose, WTO agreements are not in principle among the rules, in the light of which the Court is to review the legality of measures adopted by the EU institutions ${ }^{75}$. The exceptions are the following two situations: first, where the EU intends to implement a particular obligation assumed in the context of those WTO agreements, and second, where the EU's acts at issue refer explicitly to specific provisions of those agreements. ${ }^{76}$ Due to the absence of specific rules relating to the method of calculating normal value originated from NME countries in the WTO agreements, the ECJ concluded that Art.2(7) cannot be considered to be a measure intended to ensure the implementation in the EU legal order of a particular obligation assumed in the context of the WTO. ${ }^{77}$

3. Following the logic applied by the ECJ, direct correlation between Art.15 of the Accession Protocol and Art.2(7) of the Basic AD Regulation also cannot be established, as Art.15 only calls for countries to refrain from using strict comparison when Chinese products were under investigation. ${ }^{78}$ The judgment of 4th February, 2016 concerning imports of footwear with uppers of leather originating in China and Vietnam ${ }^{79}$, further confirmed the ECJ approach in terms of how the ECJ assesses the effects of the WTO agreements on the legal order of the

72 OJ 1996 L 56, p.1.

73 T-512/09, EU:T:2013:571.

74 ECLI:EU:C:2015:494.

75 ECLI:EU:C:2015:494, para.37-38.

76 ECLI:EU:C:2015:494, para.40-41.

77 ECLI:EU:C:2015:494, para.49-53.

${ }^{78}$ Compare to Procedures for on-the Spot Investigations Pursuant to Paragraph 7 of Article 6 GATT, and Article 2 of ADA, Art.15 of Accession Protocol of China goes one step ahead in clarifying the conditions of using non-strict comparison method in calculating normal value. However, NME was not used in the provision, and the detailed rules in calculating were also absent.

${ }_{79}$ C\&J Clark International and Puma, C-659/13 and C-34/14, EU:C:2016:74. 
EU. ${ }^{80}$ In this case, the court pointed out that to accept that the EU judicature has the direct responsibility for ensuring that EU law complies with the WTO agreements would effectively deprive the EU's legislative or executive bodies of the discretion which the equivalent bodies of the EU trading partners' enjoy. ${ }^{81}$ Therefore, the legality of Art.2.7 is not about to be challenged if EU continued to apply NME method to products originating from China after the expiration of Art.15 of the Accession Protocol, as Art.2(7) cannot be considered to be a measure intended to ensure the implementation of a particular obligation contained in Accession Protocol, within the EU legal order. In this regard, resorting to any remedial action through Court of Justice of the European Union (CJEU) would be difficult for Chinese producers.

4. It has been argued that the NME list, and the conditional ME list adopted by the Basic AD Regulation have more political impact rather than legal and economic concern, ${ }^{82}$ if there were any. Different from the previous amendments, after the adoption of the Treaty on European Union and the Treaty on the Functioning of the European Union ("TFEU"), ${ }^{83}$ European Parliament gained co-decision power with European Council according to Art.207(2). ${ }^{84}$ Through "ordinary legislative procedure", the Parliament gained legislative power over almost all EU acts, which covers nearly 80 areas of issues. However, in May 2016, 6 months before the expiration date stipulated in Art.15 of the Accession Protocol, the European Parliament through resolution; which is a non-legislative decision in nature; with an $83 \%$ majority voted against granting China market economy status. ${ }^{85}$ This resolution sent a strong signal to the European Commission and

80 A lot has been written on the place of WTO law in EU legal order. See for instance, Marco Bronckers, "The Effect of the WTO in European Court Litigation", Texas International Law Journal 40 (2005), pp. 443-448, Marco Bronckers, "The Relationship of the EC Courts with Other International Tribunals: Non-committal, Respectful or Submissive?”, Common Market Law Review 44 (2007), pp. 601-627, Luca Barani, Relationship of the EU legal order with WTO law: Studying Judicial Activism, GARNET (Working Paper No: 70/09 September 2009), Thomas Cottier, The Implications of EC - Seal Products for the Protection of Core Labour Standards in WTO Law, (Springer, 2018), etc.

81 Id, para.86.

82 Liliana Popescu, "The NME Status of the Republic Moldova and the Market Economy Status of Ukraine and Russia: A Political Decision of the European Union and its Implications within the WTO Legal Framework", 5 Global Trade and Customs Journal 3, 2010, pp.113-119; European Commission, Inception Impact Assessment: Possible change in the methodology to establish dumping in trade defense investigations concerning the People's Republic of China, 10 February 2016; "European Commission Weighs Four 'Mitigating' Steps to Blunt China MES”, Inside U.S. Trade, 4 February 2016; Gary Hufbauer and Cathleen Cimino-lsaacs, The Outlook for Market Economy Status for China, Peterson Institute for International Economics, 11 April 2016, available at: https://piie.com/blogs/trade-investment-policy-watch/outlook-market-economy-status-china (accessed on 1 June 2017).

83 OJ C83/140 30.03.2010.

84 Art.207(2) of the TFEU:" The European Parliament and the Council, acting by means of regulations in accordance with the ordinary legislative procedure, shall adopt the measures defining the framework for implementing the common commercial policy."

85 European Parliament Resolution of 12 May 2016 on China's Market Economy Status $(2016 / 2667(\mathrm{RSP}))$. 
Council that they must not be too hasty in granting China market economy status, as doing so would cost Europe job losses in key industries, such as steel.

5. The resolution adopted by the Parliament indicated that, aside from using or not using the third country method in calculating normal value pursuant to Art.2(7), there was a third way, which is, continue to apply special treatment for Chinese producers. In other words, China remains in the conditional ME list, and Art.2(7)(c) continues to apply in categorizing Chinese individual producers. As for producers who fail to reach the 5 criteria contained in Art.2(7)(c), domestic price continues to be disregarded even though the third country method no longer is an option due to the pressure arising from EU's WTO obligation. Already in a legislative decision adopted in 2001, ${ }^{86}$ the European Council recognised that, considering China was an economy in transition, ${ }^{87}$ the deviation from regular anti-dumping mechanism under the WTO law shall last for 15 years from the date of China's accession. ${ }^{88}$ The legality of such sunset provision may arguably be threatened by the resolution adopted by the Parliament in 2016. Although it can be said that such a non-legislative resolution shall not be interpreted as amending the Council Decision adopted in 2001, the resolution clearly serves as merely a political barrier, while the EU is willing to pay for the cost, even though it is an expensive one.

\section{The New Legislation}

1. The European Commission issued a new proposal regarding the amendment of Basic Anti-Dumping Regulation on 9 November 2016,89 amending the previous methodology on the affirmation of normal value. The NME treatment is no longer mentioned according to the new proposal, whilst a new provision has been proposed to calculate normal value away from using domestic prices of the export country, when "significant distortion" occurs. The European Parliament approved such amendment on 15 November 2017 and a new "country-neutral" methodology was adopted, which replaced the previous NME country list subject to normal value examination under new initiated anti-dumping investigations. ${ }^{90}$

\footnotetext{
86 Proposal for a Council Decision establishing the Community position within the Ministerial Conference set up by the Agreement Establishing the World Trade Organization on the accession of the People's Republic of China to the World Trade Organization. OJ C 51E, 26.2.2002.

87 id, para.54.

88 id, para. 55.

89 European Commission, "Proposal for a Regulation of the European Parliament and of the Council Amending Regulation (EU) 2016/1036 on Protection Against Dumped Imports from Countries not Members of the European Union and Regulation (EU) 2016/1037 on Protection Against Subsidized Imports from Countries not Members of the European Union", Brussels, 9.11.2016, $\operatorname{COM}(2016) 721$ final.

90 The parliament adopted the rules with 554 votes for, 48 against and 80 abstentions. See: http://www.europarl.europa.eu/news/en/press-room/20171110IPR87817/parliament-passes-new-a nti-dumping-rules-to-protect-eu-jobs-and-industry (visited on 28th November 2017)
} 
2. In the new regulation, the previous Article 2(7) was replaced by a new provision, namely Article 2(6)(a), which spells out exactly how to construct an undistorted value by using benchmarks or data from similar countries when domestic prices were contaminated by significant market distortions. Although for WTO Members normal value is usually based on the domestic prices of the like product, there are circumstances in which normal value shall be constructed on the basis of costs of production and sale reflecting undistorted prices or benchmarks. Constructive normal value is applied when prices or costs are not the result of free market forces because they are affected by government intervention. Relevant considerations have been enumerated in the new regulation, such as, "the fact that the market in question is subject to a policy supervision or guidance of the authorities of the exporting country, the state presence in firms allowing the state to interfere with respect to prices or costs, the existence of public policies or measures discriminating in favour of domestic suppliers or otherwise influencing free market forces, and the access to finance granted by institutions implementing public policy objectives."’1

3. In addition to the "market distortion" criteria, the new regulation makes it clear that the new system is only subject to investigations initiated after the entry into force of the amended provisions, while the investigations initiated before shall remain governed by the current disciplines. ${ }^{92}$ A “transition" period was incorporated into the amended regulation, which stipulates that reviews of existing measures should only be applied if the factual circumstances of the exporters have changed to an extent that the current level of measures is shown to be no longer appropriate. If a review is initiated as a result of an objective change in the circumstances of an exporter, the review could still be conducted on the basis of the current methodology if the specific circumstances that led to the application of the current methodology have not changed. ${ }^{93}$

4. The following three major changes were incorporated in the new legislation. First, the five criteria in determining market economy ${ }^{94}$ no longer exist. Instead, once the existence of significant distortion is recognised ${ }^{95}$ in a certain country or a certain sector of the country by the report produced by the Commission, ${ }^{96}$ domestic prices and costs in the exporting country shall

91 Ibid, Explanatory Memorandum.

92 Ibid.

93 Ibid. Article 11(3).

94 1225/2009, Article 2(7).

95 Among other things, according to the new EU report, an economy is significantly distorted

"...when reported prices or costs, including the costs of raw materials and energy, are not the result of free market forces because they are affected by substantial government intervention". See the relevant part of point (b) of Article 2(6a) of the new EU legislation which also lays down conditions that will be taken into account when considering whether a particular market is significantly distorted. See also the introductory note to the report on China in European Commission Document, SWD(2017) 483 final/2 (20 December 2017).

96 Article 2(6), paragraph C, "the Commission shall produce, make public and regularly update a report describing the market circumstances". The term 'non-market economy' was not mentioned, 
be disregarded, and constructed value shall be applied. Accordingly, once China or a sector in China is marked as significantly distorted, Chinese producers shall have no legal ground to argue for the application of their domestic price. Furthermore, the EU industry may rely on the evidence in the report in order to justify the calculation of the normal value. ${ }^{97}$ Compared with the previous five criteria for market economy treatment application, the new method seemingly deprives individual producers the opportunity of applying domestic prices in anti-dumping investigations. ${ }^{98}$ Second, Article (6)(a) paragraph (b) defines significant distortion as prices or costs that are not the result of free market forces because they are affected by substantial government intervention. The European Commission issued a working document elaborating significant distortions in the economy of China, which specified that the elements of assessing includes raw material, energy, land, capital, and labour. ${ }^{99}$ This 465 pages report examines the core features of the current shape and structure of Chinese economy, which include the very concept of a 'socialist market economy' and the rule of Chinese Communist Party in relation to the economy. It further focuses on the provision of land, energy, capital, material inputs and labour in China, with a conclusion that the allocation and pricing of the various factors of production is influenced by the State in a very significant manner. This report also examines a number of key trade sectors, namely, steel, aluminium, chemicals, and ceramics, ${ }^{100}$ and the conclusion of such examination also indicates that various factors of production render significant distortions to the above sectors. ${ }^{101}$ With the guidance of such working document, the Commission is inclined to target China or specific trade sectors of China as significantly distorted. Hence, domestic prices in China may easily be disregarded under EU's anti-dumping investigation. Third, Article (6)(a) specified the detailed methods in which normal value will be calculated when significant distortion occurs. Accordingly, corresponding costs of production and sale in a representative country, undistorted international prices, costs, or benchmarks, and domestic prices provided that they are positively established not to be distorted, are available alternatives for the replacement of domestic prices. It should be noted that, unlike the "surrogate country" methodology, the new legislation stipulates that "normal value shall be constructed 'exclusively' on the basis of costs of production and sale reflecting undistorted prices or benchmarks". ${ }^{102}$ Hence, there are two approaches in normal value determination under the new

and no WTO member was explicitly named in the new regulation.

97 Article 2(6) paragraph d.

98 Unless individual producer's domestic costs are positively established not to be distorted with accurate and appropriate evidence, see Article 2(6) paragraph a.

99 European Commission, Commission Staff Working Document on Significant Distortions in the Economy of the People's Republic of China for the Purposes of Trade Defense Investigations, SWD(2017) 483 final/2, Brussels, 20.12.2017.

100 Ibid, p.3. "These sectors have been selected because they are the ones that have featured most in the EU's anti-dumping investigations since the conclusion of the Uruguay Round."

101 Ibid, pp.346-375.

102 See: European Commission, How to Make An Anti-Dumping Complaint-A Guide, Paragraph 66: "Once the existence of significant distortions for the product concerned is established, the normal value must be constructed on the basis of costs of production and sale reflecting undistorted prices 
legislation: the domestic prices or the constructed prices when significant distortions exist in the market or the trade sector. The following section analyses the extent to which the above mentioned new methods is compatible with WTO law.

\section{WTO Jurisprudence and Its Influence over EU Municipal Law}

1. Under Article 2.1 of the ADA, normal value shall be determined by the domestic prices of the exporting country, provided that such comparable price is available in the ordinary course of trade. Alternatively, consistent with Article 2.2, normal value may also be determined by reference to the export price of the like products to a third country, or a constructive normal value ["CNV"] under certain circumstances. ${ }^{103}$ Once CNV is applied, it shall include the cost of production in the country of origin plus a reasonable amount for administrative, selling and general costs ("SG\&A) and for profits. With the expiration of Paragraph 15 of the Accession Protocol, alternative methods other than strict comparison should normally find its legal basis under Article 2.2, as no specific action against dumping can be taken other than in accordance with ADA. ${ }^{104}$ Should the EU's new legislation be compatible with WTO law, the notion of 'significant distortion' as well as its application shall fall within the circumstances that allowing the application of non-strict comparison stipulated under Article 2.2. Analysing the compatibility issue in light of relevant WTO jurisprudence, this article finds that the precondition of applying non-strict comparison under the EU's new legislation may infringe WTO law. Furthermore, the approach of constructing normal value stipulated in the new legislation "as such" and "as applied" may be inconsistent with W'TO law.

2. The only precondition for applying CNV under EU's new legislation is when there is the existence of significant distortion in exporting member's market. The predominant reason that causes "significant distortion" is substantial government intervention. ${ }^{105}$ Hence, under the EU's current legislation, once significant distortions were recognised by the Commission, CNV shall be applied. However, the jurisprudence of WTO law runs contrary to such logic. The alternative approach other than strict comparison is stipulated under GATT Article VI:1 and Article 2.2 ADA. GATT Article VI:1 only enables the application of CNV when comparable domestic price is absent, ${ }^{106}$ while Article $2.2 \mathrm{ADA}$ elaborates the reasons why comparable domestic price is

\footnotetext{
or benchmark, including a reasonable amount of SG\&A and profit."

103 Under Article 2.2 ADA, special circumstances include: "when there are no sales of the like product in the ordinary course of trade in the domestic market of the exporting country", when particular market situation occurred, or when the sales volume in domestic market of the exporting country is low.

104 Article 18.1 ADA: "No specific action against dumping of exports from another Member can be taken except in accordance with the provisions of GATT 1994, as interpreted by this Agreement."

105 Article 2(6)a, paragraph b. 2017/2321

106 Article VI:1(b)(ii) GATTT.
} 
absent.

3. The phrase Particular Market Situation is included in the provision, although its scope remains unclear. As has been discussed above, under the WTO dumping is normally determined by comparing home prices of the exporting country to the export prices. ${ }^{107}$ However, consistent with AD Agreement Article 2.2, in the absence of 'comparable price of the like product when exported to an appropriate third country', dumping may be determined on the basis of production cost in home country 'plus a reasonable amount for administrative, selling and general costs and for profits' when there exist a PMS which may inhibit a proper comparison with export prices. The Ad Note to Article VI:1 further provides the basis for non-strict comparison. However, the application of Ad Note to Article VI:1 is very restrictive. It is only applicable when a market is under complete or substantially complete State monopoly. ${ }^{108}$ In EC-Fasteners, the Appellate Body further clarified that the benchmark of applying Ad Note to Article VI:1 is extremely high. ${ }^{109}$ Accordingly, such note is almost impossible to apply to any transitional economy nowadays. Hence, Ad Note to Article VI:1 provides limited reference to the scope of PMS. It is noted that the WTO jurisprudence mainly focuses on the application of PMS instead of defining the actual scope of the same. Recalling the negotiating history of GATT Article VI and ADA, some commentators have observed that a PMS would arise "only if the situation in concern precludes a proper comparison between export price and normal value". ${ }^{110}$ Such observation is in line with WTO jurisprudence. And on the basis of the 2017 EU's report on China, it is difficult to see how PMS will not arise when calculating the margin of dumping. Under Article 2.2 ADA, in order to apply CNV, a causal link between the existence of PMS and the exclusion of proper comparison must be presented.

4. In EC-Cotton Yarn, a GATT Panel found that PMS was only relevant "insofar as it had the effect of rendering the sales themselves unfit to permit a proper comparison"111. In EU-Biodiesel,

107 AD Agreement Article 2.1.

108 GATT Analytical Index, p.228-229. Available at:

https://www.wto.org/english/res_e/booksp_e/gatt_ai_e/art6_e.pdf (accessed in January 2018); Also see: Terence P. Stewart (ed), The GATT Uruguay Round: A Negotiating History (1986-1992) (Volume II), Kluwer Law and Taxation Publishers, 1993. pp.1404-1406. This Ad Note was agreed in the Review Session of 1954-1955, it is a reflection of the Report of the Working Party on the Accession of Poland, Romania and Hungary, due to their special market situation at that time. The Committee on Anti-Dumping Practices established under the 1979 Agreement on Implementation of Article VI of the General Agreement on Tariffs and Trade records that: "In the case of imports from a developing country, the fact that the export price may be lower than the comparable price for the like product when destined for domestic consumption in the exporting country does not per se justify an investigation or the determination of dumping unless the other factors mentioned in Article 5:1 (currently Article 2.2 ADA) are also present". See: GATT Analytical Index, p.229

109 The Appellate Body held that the two conditions, namely, a country which has a complete or substantially complete monopoly of its trade, and where all domestic prices are fixed by the state, must be fulfilled cumulatively in order to make the Note applicable. EC-Fasteners, Appellate Body Report, n.460.

110 Zhou and Percival (2016), p.881.

111 EC-Imposition of Anti-Dumping Duties on Imports of Cotton Yarn from Brazil, GATT Panel Report, 42S/17. 
the Appellate Body held that the distorted domestic production costs due to Argentine export tax system was not, in itself, a sufficient basis for concluding that those costs needed to be disregarded. ${ }^{112}$ It can be seen that PMS may refers to a wide range of issues that rendered the domestic price artificially low, it is nevertheless insufficient to trigger the application of CNV, unless a causal relationship exist between PMS and the exclusion of a fair comparison between export price and normal value. Significant distortion and the precondition of applying $\mathrm{CNV}$ in the EU's new legislation may be categorised as a form of PMS, but the lack of a causal relationship between significant distortion and the exclusion of fair comparison maybe contrary to the current WTO jurisprudence. Furthermore, in the anti-dumping investigations initiated by EU toward China, Article 2(6)(a) of the EU's new legislation seems to be inconsistent with Paragraph 15(a) of Accession Protocol. A case may be made with regard to Paragraph 15(a)(ii) as the only justification for non-strict comparison regarding Chinese products. According to the analysis carried out above, such justification already expired in 2016, and no other alternatives are indicated by the wording of Paragraph (d). Therefore, in the absence of new legislation in the EU, they are obliged to provide strict comparison in anti-dumping investigations towards China.

5. Moreover, Article 2(6)a of the EU's new legislation as such arguably contravenes WTO law. In Article 2(6)(a), CNV is based on the costs of production and sale reflecting undistorted prices or benchmarks. The Commission refers to third country and international prices, costs or benchmarks as alternatives of domestic costs of exporting country, while directly disregarding the cost of production from exporting member. ${ }^{113}$ In contrast, Article 2.2 ADA requires that the $\mathrm{CNV}$ shall be built upon a comparable price of the like product when exported to third country, or with the cost of production in exporting member plus a reasonable amount for SG\&A and for profits. It does not seem to be in line with Article 2.2.1.1 ADA which elaborates the calculation of CNV under non-strict comparison. ${ }^{114}$ In addition, Article 2(6)(a) of EU's new legislation does not contain specific method in determining undistorted SG\&A and profit, which may expand the powers of the investigating agency. Accordingly, Article 2.2.2 ADA is disregarded.

6. Furthermore, Article 2(6)(a) of the EU's new legislation "as applied" is arguably not in line with WTO law. Article 2.4 ADA requires that "a fair comparison shall be made between the export price and the normal value" and that any differences which affect price comparability shall be subject to adjustment. The method of constructing CNV under the EU's new legislation

\footnotetext{
112 EU-Biodiesel, Appellate Body Report, para. 6.55.

113 Under Article 2(6)a paragraph a, domestic costs is available, but only to the extent that they are positively established not to be distorted, on the basis of accurate and appropriate evidence. Such provision renders the burden of proof to exporting members' producers, which is also a violation of Article 2.2 ADA.

114 By the same token, EU's new legislation also violates Article VI:1 GATT, which uses the costs of production of the product in the country of origin as an element in constructing $\mathrm{CNV}$, no other alternative is provided.
} 
without a mandatory adjustment requirement affects the fair comparison stipulated under the ADA. ${ }^{115}$ Moreover, GATT Article VI:2, and ADA Article 9.1 and 9.3 require that members shall levy anti-dumping duty less than the margin of dumping in respect of such product, and lesser duty would be desirable if such lesser duty were adequate to remove the injury to the domestic industry. Under the EU's new legislation, the Commission is most likely to adopt higher CNV in the comparison with export prices. Under such circumstance, the margin of dumping may be easily inflated, and the obligation underlined by Article GATT VI:2, and ADA Article 9.1 and 9.3 may be derogated.

\section{CONCLUSION}

1. Paragraph 15 of the Accession Protocol might have expired in December 2016, but the substantive content of the concept of NME in the calculation of dumping margin in the EU has not disappeared. The concept of 'significant distortions' due to state interference, introduced in the new EU's country-neutral legislation still allows the EU investigating authorities to calculate normal value away from using domestic prices of the export country. Accordingly, such calculation may include cost of production and sale in an appropriate third country that is at a similar level of development as the country under investigation. There are a number of issues with this new EU's legislation and how it may apply to imports from China.

2. Firstly, 'significant distortions' is defined as an economy that "prices or costs, including the costs of raw materials and energy, are not the result of free market forces because they are affected by substantial government intervention". 116 Although the 2017 EU's report assessing the nature of the economy of China, finds that "China has moved from a system where essentially all prices are set by the State" to a more complex system, prices of pharmaceuticals, "fuel, electric power, and other utilities" are still fixed by the state. Moreover land allocations and other prices are distorted as they are subjects to state intervention and therefore, do not operate on the basis of free market. This assessment means that it is almost certain that EU's investigating authorities will almost always find dumping whenever an investigation is initiated against Chinese imports. Secondly, the notion

115 The adjustment requirement is a controversial issue in WTO jurisprudence. In EU-Footwear, "Fair comparison" was referred to the procedure of comparison, rather than normal value or export price per se. See: European Union-Anti-Dumping Measures on Certain Footwear from China, WT/DS405/R, para.7.265. However, in US-Hot-Rolled Steel, the Appellate Body found that CNV and export price shall be adjusted to ensure a fair comparison. See: Appellate Body Report, United States-Anti-Dumping Measures on Certain Hot-Rolled Steel Products from Japan, WT/DS184/AB/R, para.177. While in the compliance proceeding of EC-Fasteners, both the Panel found that the adjustments in costs may not be required. See: Panel Report, EC-Fasteners (Recourse to Article 21.5 of the DSU by China), para.7.245. However, the EC-Fasteners Compliance case is specifically targeting the situation where the analogue country methodology is used under the NME assumption, the application of the ruling should be regarded as limited.

116 See Section 2.2.2 of the report. 
of appropriate third country at similar level of development is a bit puzzling. Even if the EU uses the World Bank's methodology on the classification of countries, ${ }^{117}$ there is no definition of a developing country. While GDP per capita is employed to identify least developed countries in the WTO, the same cannot be said for developing countries as countries self-select themselves. ${ }^{118}$ Moreover, it is difficult for two countries to be exactly the same. For instance, even without government intervention in China, utility prices and the cost of labour in China may hardly be the same as in India.

3. Moreover, if the expiry of the NME classification of China means that China is now a market economy, it may arguably be difficult to justify, under WTO law, the use of 'benchmark' or costs of production and sale in a third country when calculating dumping margin. There may be a case on using constructed prices when appropriate based on China's domestic prices. Yet, while the EU new legislation is country-neutral and does not specifically labels China as a NME, the 2017 report on the nature of China's economy ${ }^{119}$ is unequivocal about 'significant distortions' in China's economy as a consequence of state interference. Therefore, the expiry of Paragraph 15 of the Protocol of Accession of China does not mean that China will be seen as an economy that operates on the basis of market forces for the purpose of EU's antidumping rule. The significance of the new EU's legislation is not the idea of country-neutral approach but rather the fact that it gives European Commission the flexibility to establish significant distortion and therefore, the use of third country costs.

4. Despite the fact that the jurisprudential progressivism of the WTO is less clear on the notion of 'significant distortion', this concept in the EU's new legislation seems to lend support in the long-standing issue of PMS, which is viewed as part of the Uruguay Round unfinished debates on 'input dumping. ${ }^{120}$ It is however, fair to point out that although the new EU legislation is yet to be challenged before the WTO, the flexibility engrained in the notion of PMS means that, it is difficult to state with certainty how the new EU country-neutral report on 'significant distortions' will be interpreted by the WTO adjudicatory body. Irrespective of the fact that the notion of input dumping has not been historically linked to state intervention, the notion of 'significant distortion' in the new EU's legislation cannot be decoupled from the activities/intervention by a

117 See the World Bank's Data on the list of 47 least developed countries. Available at https://data.worldbank.org/?locations=XL-NP (visited March 2018).

118 The term developing country is really an imprecise term based on political, economic and social foundation as well as how other countries perceive a country.

119 European Commission Document SWD(2017) 483 final/2, (20 December 2017).

120 See GATT document MTN.GNG/NG8/W/26/Rev.1 (25 May 1988), the following definition has been given to "input dumping" "... a situation where materials or components used in manufacturing and exported product are purchased internationally or domestically at dumped or below cost prices, whether or not the product itself is exported at dumped prices". See Submission of Japan on the Amendments to the Anti-dumping Code, MTN.GNG/NG8/W/48/Add.1 (29 January 1990), para. VI. 
state. This means that in as much as the EU continue to view China's economy as not operating free from state intervention, it would be difficult for the issue of third country cost in the calculation of dumping margin to ebb away. Going forward, WTO members will have to re-think broadly the issue of dumping/anti-dumping as currently regulated by the multilateral trading system. More precisely, the issue of PMS, input dumping as well as the notion of 'significant distortions' raised in the new EU's legislation will need proper discussion by the negotiating arm of the WTO. It is the entire WTO membership that ought to have the last say and clarify the antidumping rules so as to first, ensure a level-playing field in the system and secondly, ensure that some WTO members are not targeted for engaging in legitimate trade practices. 


\section{China's Market Economy Dilemma and its Interplay with EU Anti-Dumping Law}

Yenkong Ngangjoh-Hodu* and Tianzhu Han**

*Professor and Chair of International Economic Law, The University of Manchester School of Law. Contact: yenkong.ngangjohhodu@manchester.ac.uk

** Dr. Tianzhu Han is Assistant professor in Shandong University of Science and Technology, China. Contact: hanxiao6881@163.com 